\title{
INTERVENTION IN ROMA \\ COMMUNITIES. PARTICIPATION IN FORMATION ACTIVITIES
}

\author{
Corina $\mathrm{CACE}^{1}$
}

DOI: 10.35782/JCPP.2019.1.04

\begin{abstract}
The study developed within an integrated program follows the actions carried out on the labour market for the employment of the Roma population. Are these measures effective and respond to the needs of the Roma population or the lack of adequacy to the specifics of the population leads to poor results? Data collection methodology included face-to-face questionnaire interviews with predefined questions, administrated by trained field operators. A total of 1064 questionnaires with Roma people were also collected. The marginalised Roma persons have been selected using the "snowball" method (we started from the town hall; if we had no success with the town hall, we approached the next institutions that might supply such information, for instance, the church, health care unit, police, school etc.). A percent of 13\% of the respondents declared that they attended professional training courses after having graduated the school. The respondents who attended training courses after having graduated the school, attended training courses in mechanics and plumbing (26\%), in constructions (16\%), catering and services (14\%), counselling and formation (12\%). Less than 10\% of these respondents attended training courses in other areas.
\end{abstract}

Keywords: regional development, social development, employment, vocational training, Roma communities

\section{Introduction}

This study has been conducted within project "OPTIMAL- Establishment and development of a network of Centres of Social Inclusion for the Roma", project co-financed from the European Social Fund through the Sectoral Operational Program Human Resources Development 2007-2013 "Invest in people", implemented by the Association for Socio-Economic Development and Promotion Catalactica, Bucharest, in partnership with the Foundation for Social Recovery Integration and Development ECHOSOC Bucharest, and the Association for Integrated Development, Olt, Slatina.

General objective of the project was to facilitate the access to labour market for a number of 1,088 Roma people from the rural areas covered by a network of 4 Centres

1 Professor Phd., Teacher Training Department, Bucharest Academy of Economic Studies. E-mail: corina.cace@gmail.com 
of Social Inclusion for the Roma (CSIR) from the 4 southern regions of development in Romania: South-East, South-Muntenia, South-West Oltenia and Bucharest-Ilfov, in order to prevent their social exclusion and marginalisation, and to avoid discrimination and the risk of poverty.

The effects generated by the project considered not just improving the participation of the vulnerable groups to the labour market, but also the establishment of conditions for their subsequent development.

By its design and objectives, the project pursued three main directions:

1. Development of the personal capacities of the people from the vulnerable groups regarding their access to labour market, by supplying integrated and specialised services (education, formation, information, counselling, market labour orientation, assistance in finding and getting a place of work);

2. Encouraging, by activation and mobilisation of the local communities and employers, to identify viable solutions to increase the level of professional insertion of the Roma people and to use their potential in a manner that ensures both the cohesion, and the social equity within the targeted communities.

3. Implementation of a set of measures adapted both to the specific needs of the target group, and to the opportunities circumscribed within the socio-economic context of the communities where the project is to be implemented, by scientific documentation, quantitative research and qualitative evaluation of the activities performed within the project, as well as of their impact on the target groups.

Any explanative action with actional finalities requires deepening the Roma problem detached from the existential context of the people belonging to the community. We focused our analysis on the segment of rural Roma population, whose structural conditionality's we will discuss for the 4 regions of development, where the planned interventions are to be conducted. We analysed the 4 regions in a unitary manner, given the existing similitudes between them. At the same time, an analysis at the county level was conducted, on the specificity of each region.

\section{Methodology}

The quantitative research within the project corresponded to activity 4. Evaluation of the occupational needs of the Roma people, and of the impact of the support interventions provided within the marginalised communities of Roma in rural areas, being in accordance with the specific objectives 1 and 2 of the project.

Specific objective 1. Facilitate the access to occupation for a number of 1,088 Roma people, from the rural areas, of which 450 women, from regions South-East, SouthMuntenia, South-West Oltenia and Bucharest-Ilfov, by providing, complementary to the support of the local volunteers, services of professional information and counselling, and services of social work and psychological assistance, to motivate them to integrate/reintegrate on the labour market, within 4 Centres of Social Inclusion of the Roma. 
Specific objective 2. Increase the level of insertion on the labour market and labour force mobility by diversified and tailored professional formation, within the community, based on the evaluation, within the areas covered by the Centres, of 896 Roma people from South-East, South-Muntenia, South-West Oltenia and BucharestIlfov, by certifying at least 716 trainees.

Specific activities have been performed within activity 4, to evaluate the employment requirements of the Roma people from 56 marginalised Roma communities, using a methodology relying on scientific research criteria. This activity was completed by the analysis of the impact of the support services provided within the marginalised Roma communities, validated by 4 focus-groups in which participated experts in the field of the social inclusion of Roma people. This evaluation supported directly project activities, i.e., determination of the covered areas (Activity 5), selection and particularization function of the communities, of the 8 programs of professional formation (Activity 6), and the supply of scientifically-validated information to promote the employment opportunities for the Roma within the covered areas (Activity 7). The main target group of this project consisted of Roma people. The research activities of the project were performed during months 1-6 of implementation, namely, April 16-October 16, 2014.

The research started with a desk-research, whose purpose was to make a regional analysis whose results were used both to produce the samples of the quantitative research (the list with the 56 marginalised Roma communities), and to select and justify the counties where the 4 CISR were to be established. The same analysis outlined a brief evaluation of the requirements for professional formation by regions and counties. Based on this evaluation we selected 2 type of professional formation adequate for the Roma from the 8 courses of professional training. The rest of 6 types of professional formation were identified based on the data collected during the field research and by in-depth analysis of secondary data. The research experts conducted this desk-research on data from ANOFM, INS, from previous research, unofficial data from NGOs and experts in this field.

Sampling: we selected 54 rural communities and 2 urban communities from Bucharest, running a higher risk of marginalisation/social exclusion. We selected 6 communities from each of the 4 counties where the CISR have been established, and 2 communities from each of the other 15 counties, plus 2 communities from Bucharest.

Research target: Roma population, aged 18-64, from the 56 selected communities.

Sample: $n=1400$ respondents. The error margin was $2.6 \%$ with $95 \%$ level of confidence. The marginalised Roma persons have been selected using the "snowball" method (we started from the town hall; if we had no success with the town hall, we approached the next institutions that might supply such information, for instance, the church, health care unit, police, school, etc.). This type of sampling allowed us to identify the people fitting the selection criteria to be included in the study; they were subsequently asked to recommend other people they know, that meet these criteria. Each field operator interviewed at least 19 marginalised Roma people, and 2 representatives of the public institutions (school, town hall, police, public administration), health care units or church. 
Data collection methodology: face-to-face questionnaire interviews with predefined questions, administrated by trained field operators. Data collection was conducted between June 16, 2014 August 16, 2014. A total of 1064 questionnaires with Roma people were collected, and 112 questionnaires with representatives of the public authorities. The breakdown by region is as follows:

- Bucharest-Ilfov region: a total of 152 questionnaires with Roma people and 16 questionnaires with representatives of the public authorities. Of the total: in Bucharest, 38 questionnaires with Roma people and 4 questionnaires with representatives of the public authorities; in Ilfov County, 114 questionnaires with Roma people and 12 questionnaires with representatives of the public authorities;

- South-East region: a total of 304 questionnaires with Roma people and 32 questionnaires with representatives of the public authorities. Of the total: in Constanța, Tulcea, Brăila, Vrancea and Buzău counties, 38 questionnaires with Roma people and 4 questionnaires with representatives of the public authorities; in Galați County, 114 questionnaires with Roma people and 12 questionnaires with representatives of the public authorities;

- South-West Oltenia region: a total of 266 questionnaires with Roma people and 28 questionnaires with representatives of the public authorities. Of the total: in Gorj, Mehedinți, Olt and Vâlcea counties, 38 questionnaires with Roma people and 4 questionnaires with representatives of the public authorities; in Dolj County, 114 questionnaires with Roma people and 12 questionnaires with representatives of the public authorities;

- South-Muntenia region: a total of 342 questionnaires with Roma people and 36 questionnaires with representatives of the public authorities. Of the total: in Argess, Dâmbovița, Teleorman, Giurgiu, Ialomița and Călăraşi counties, 38 questionnaires with Roma people and 4 questionnaires with representatives of the public authorities; in Prahova County, 114 questionnaires with Roma people and 12 questionnaires with representatives of the public authorities.

\section{Results}

\section{Analysis of the state of professional training of the Roma people from the target marginalised communities}

The state of professional training was studied in relation with the qualification acquired by the Roma people from the target communities, and in relation with the areas of professional formation and trades of interest for the respondents. We also analysed the extent to which the interviewed Roma people and the representatives of the local authorities involved in the study, have knowledge of the running occupational programs and of solutions, from the perspective of the local authorities, for an efficient insertion of the Roma people on the labour market. 


\section{Analysis of the state of professional training}

A number of 260 respondents stated to have no qualification. Some of the respondents said they have two or more qualifications. The most frequent qualifications were in the field of mechanics and plumbing and constructions, in all surveyed regions of development. In South-East, 16 of the respondents said they have professional training in the field of counselling and formation (see Table 1).

Table 1. R11. Qualifications of the respondents, by regions, and total - Multiple answer

\begin{tabular}{|c|c|c|c|c|c|}
\hline \multirow{3}{*}{ Qualification } & \multicolumn{5}{|c|}{ Region of development } \\
\hline & $\begin{array}{c}\text { Bucharest- } \\
\text { Ilfov }\end{array}$ & $\begin{array}{c}\text { South } \\
\text { Muntenia }\end{array}$ & $\begin{array}{l}\text { South- } \\
\text { West } \\
\text { Oltenia }\end{array}$ & South-East & Total \\
\hline & \multicolumn{5}{|c|}{ Number of respondents } \\
\hline Unskilled & 85 & 171 & 212 & 146 & 614 \\
\hline Mechanics and plumbing & 13 & 41 & 15 & 25 & 94 \\
\hline Constructions & 13 & 27 & 6 & 15 & 61 \\
\hline Catering and services & 7 & 12 & 1 & 7 & 27 \\
\hline Janitor & 5 & & & & 5 \\
\hline Agriculture & 4 & 2 & 3 & 7 & 16 \\
\hline Cosmetics & 3 & 2 & 1 & & 6 \\
\hline Security agent & 2 & 5 & & 3 & 10 \\
\hline Taylor/dressing designer & 1 & 7 & 3 & 6 & 17 \\
\hline Counselling and formation & 1 & 2 & 2 & 16 & 21 \\
\hline Driver & & 5 & 6 & 9 & 20 \\
\hline Other & 5 & 13 & 5 & 16 & 39 \\
\hline
\end{tabular}

A percent of $13 \%$ of the respondents declared that they attended professional training courses after having graduated the school (see Chart 1).

\section{Chart 1. R12. Did you attend any professional training course after graduating the school? $(N=1003)$}

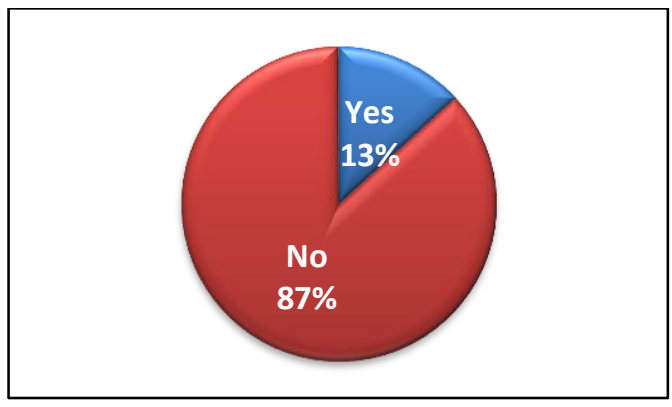


The percentage of respondents who attended training courses varies, among the surveyed regions of development, between 17.20 and 15\%, except South-West Oltenia, where just $5.40 \%$ of the respondents stated that they have attended training courses (see Chart 2).

Chart 2. R12. Did you attend any professional training course after graduating the school? $(N=1003)$, by regions of development

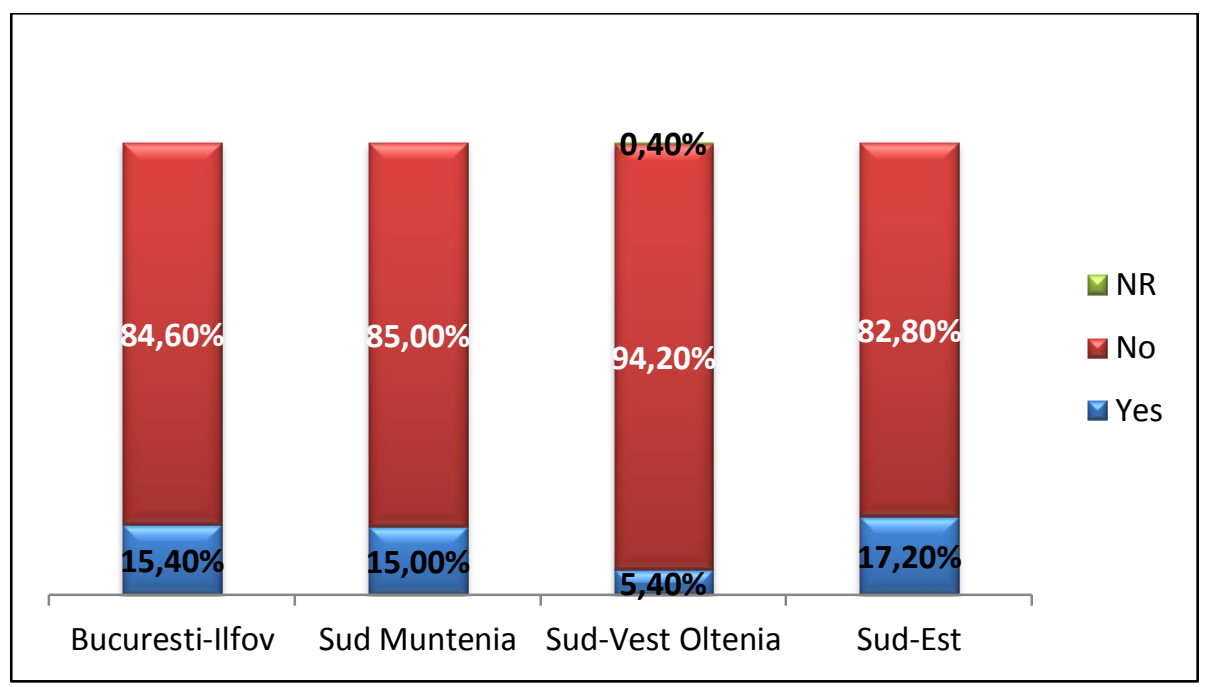

Among those who stated that they attended training courses after graduating the school, 88\% said they also received graduation/skill certificates (see Chart 3).

Chart 3. R13. Did you receive a graduation/skill certificate? $(N=123)$

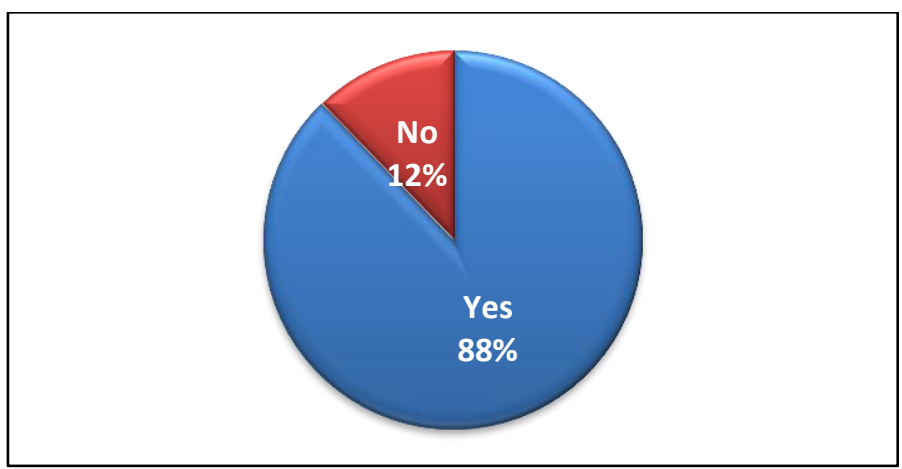


Most respondents who graduated training courses also received a diploma or certificate of graduation, in all regions of development (see Table 2).

Table 2. R13. Did you receive a graduation/skill certificate? total and by regions of development $(\mathrm{N}=123)$

\begin{tabular}{|l|l|l|l|l|l|}
\hline \multirow{3}{*}{$\begin{array}{c}\text { Certificate of } \\
\text { graduation }\end{array}$} & \multicolumn{5}{|c|}{ Region of development } \\
\cline { 2 - 7 } & Bucharest-Ilfov & South Muntenia & $\begin{array}{c}\text { South-West } \\
\text { Oltenia }\end{array}$ & $\begin{array}{c}\text { South- } \\
\text { East }\end{array}$ & Total \\
\cline { 2 - 7 } & \multicolumn{5}{|c|}{ Number of respondents } \\
\hline Yes & 16 & 37 & 12 & 43 & 108 \\
\hline No & 3 & 8 & 1 & 3 & 15 \\
\hline Total & 19 & 45 & 13 & 46 & 123 \\
\hline
\end{tabular}

The respondents who attended training courses after having graduated the school, attended training courses in mechanics and plumbing $(26 \%)$, in constructions $(16 \%)$, catering and services (14\%), counselling and formation (12\%). Less than $10 \%$ of these respondents attended training courses in other areas, as shown below (see Chart 4). Most of the training course mentioned by the respondents were of 2, 3 and 6 months.

Chart 4. R14. Type of training course attended by the respondents $(N=119)-$ Multiple answer

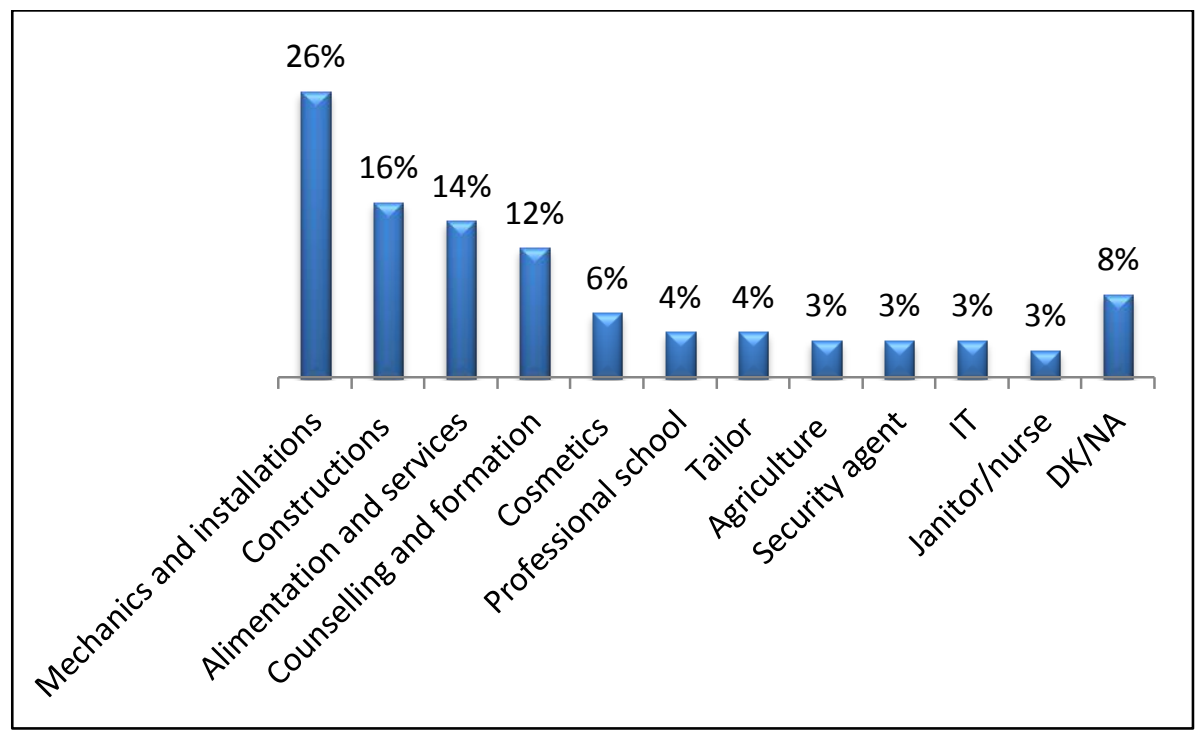

Six of 21 respondents from Bucharest-Ilfov who graduated training courses are skilled in catering and services. In South Muntenia, 17 of 46 trained people, graduated courses 
in mechanics and plumbing, and 11 of 46 are skilled in constructions. In South-East, 11 of 45 trained people, graduated courses in counselling and formation (see Table 3).

Table 3 R14. Type of training course attended by the respondents, total and by region of development $(\mathrm{N}=126)$ - Multiple answer

\begin{tabular}{|c|c|c|c|c|c|}
\hline \multirow[b]{2}{*}{ Training course } & \multicolumn{5}{|c|}{ Region of development } \\
\hline & $\begin{array}{l}\text { Bucharest- } \\
\text { Ilfov }\end{array}$ & South Muntenia & $\begin{array}{c}\text { South-West } \\
\text { Oltenia }\end{array}$ & South-East & Total \\
\hline & \multicolumn{5}{|c|}{ Number of respondents } \\
\hline $\begin{array}{l}\text { Mechanics and } \\
\text { plumbing }\end{array}$ & 3 & 17 & 2 & 9 & 31 \\
\hline Constructions & 2 & 11 & 3 & 3 & 19 \\
\hline Catering and services & 6 & 4 & 1 & 6 & 17 \\
\hline $\begin{array}{l}\text { Counselling and } \\
\text { formation }\end{array}$ & 0 & 0 & 3 & 11 & 14 \\
\hline Cosmetics & 3 & 3 & 1 & 0 & 7 \\
\hline Professional school & 2 & 3 & 0 & 0 & 5 \\
\hline Taylor & 1 & 1 & 0 & 3 & 5 \\
\hline Agriculture & 0 & 1 & 2 & 1 & 4 \\
\hline Security agent & 0 & 1 & 0 & 3 & 4 \\
\hline $\mathrm{IT}$ & 2 & 2 & 0 & 0 & 4 \\
\hline Nurse & 0 & 0 & 0 & 3 & 3 \\
\hline Other & 1 & 2 & 1 & 3 & 7 \\
\hline NS/NR & 1 & 4 & 1 & 3 & 9 \\
\hline Total & 21 & 46 & 14 & 45 & 126 \\
\hline
\end{tabular}

Asked when they attended, for the last time, a professional training course, most of the respondents replied it was no longer than one year ago, both for the whole sample (86 respondents) and by region of development (see Table 4).

Table 4. R15. When did you attend, for the last time, a course of continuous/professional formation? total and by region $(\mathrm{N}=482)$

\begin{tabular}{|l|l|l|l|l|l|}
\hline \multirow{2}{*}{$\begin{array}{c}\text { Period of attending training } \\
\text { courses }\end{array}$} & \multicolumn{5}{|c|}{ Region of development } \\
\cline { 2 - 7 } & $\begin{array}{c}\text { Bucharest- } \\
\text { Ilfov }\end{array}$ & $\begin{array}{c}\text { South } \\
\text { Muntenia }\end{array}$ & $\begin{array}{c}\text { South-West } \\
\text { Oltenia }\end{array}$ & $\begin{array}{c}\text { South- } \\
\text { East }\end{array}$ & Total \\
\cline { 2 - 7 } & \multicolumn{5}{|c|}{ Number of respondents } \\
\hline Last year & 3 & 4 & 1 & 7 & 15 \\
\hline More than one year ago & 12 & 32 & 12 & 30 & 86 \\
\hline $\begin{array}{l}\text { Do not know/do not } \\
\text { remember }\end{array}$ & 6 & 9 & 1 & 10 & 26 \\
\hline Never attended & 64 & 162 & 42 & 87 & 355 \\
\hline Total & 85 & 207 & 56 & 134 & 482 \\
\hline
\end{tabular}


Most people who attended professional training courses, evaluated than as being rather useful (96 of 111 respondents). The distribution of the positive evaluations remained the same at the level of the surveyed regions of development too (see Table 5).

Table 5. R16. How useful was what you learned at these courses? total and by region of development $(\mathrm{N}=111)$

\begin{tabular}{|c|c|c|c|c|c|}
\hline \multirow{3}{*}{$\begin{array}{c}\text { Usefulness of the training } \\
\text { courses }\end{array}$} & \multicolumn{5}{|c|}{ Region of development } \\
\hline & $\begin{array}{l}\text { Bucharest- } \\
\text { Ilfov }\end{array}$ & $\begin{array}{c}\text { South } \\
\text { Muntenia }\end{array}$ & $\begin{array}{c}\text { South-West } \\
\text { Oltenia }\end{array}$ & $\begin{array}{c}\text { South- } \\
\text { East }\end{array}$ & Total \\
\hline & \multicolumn{5}{|c|}{ Number of respondents } \\
\hline Rather useful & 12 & 39 & 11 & 34 & 96 \\
\hline Rather un-useful & 3 & 2 & 3 & 6 & 14 \\
\hline $\mathrm{NS} / \mathrm{NR}$ & & 1 & & & 1 \\
\hline Total & 15 & 42 & 14 & 40 & 111 \\
\hline
\end{tabular}

A proportion of $87.8 \%$ of the respondents would like to attend another professional training or improvement course, in the following period, if they are free and if transportation is provided. While $3.4 \%$ of the respondents would still participate in free training courses, even if transportation is not provided, $5.6 \%$ of the respondents are not interested to attend other training courses in the future. (see Chart 5

\section{Chart 5. R17. Would you like to attend a professional/improvement course in} the next period?

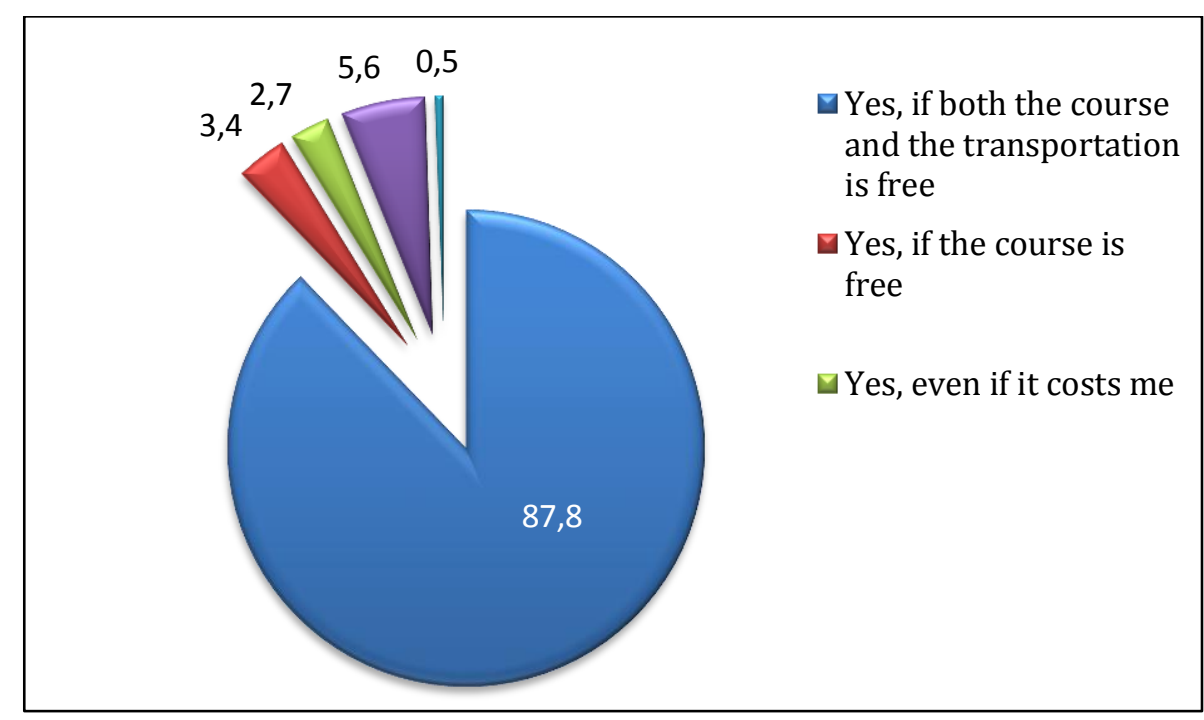


In South West Oltenia we can find the highest proportion of respondents who would like to attend free training courses $(97.3 \%)$. This category of respondent predominates in all four surveyed regions of development. In Bucharest-Ilfov and South Muntenia we can find the highest proportion of respondents who would still attend training courses, even if they presume some fees $(12.90 \%$ and $8.5 \%$, respectively). (see Chart 6)

Chart 6. R17. Would you like to attend a professional/improvement course in the next period? by region of development

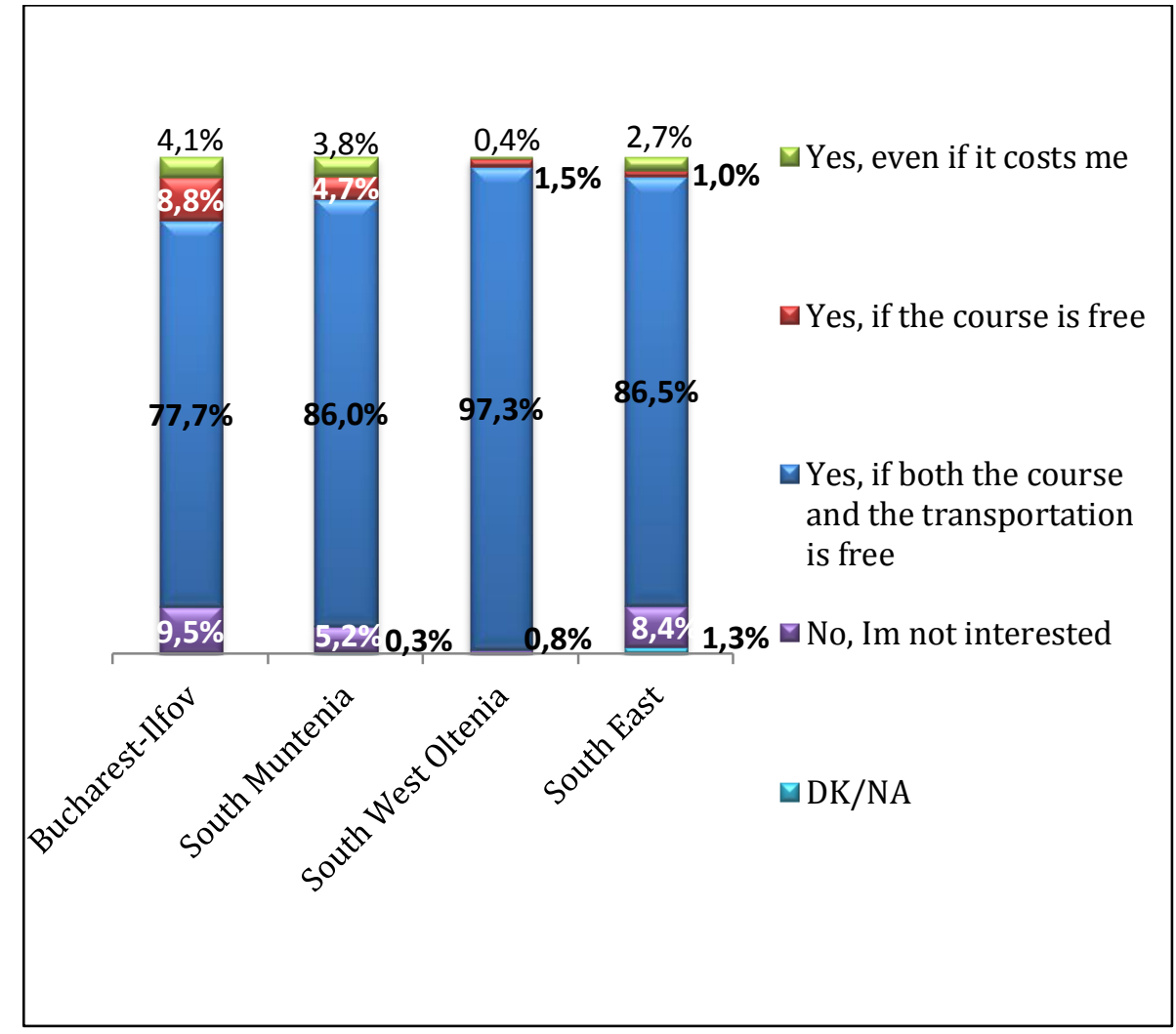

Of the respondents willing to attend training courses, 30\% would like to be trained in constructions, $19.90 \%$ in agriculture and $18.30 \%$ in commerce. Less than $10 \%$ of the respondents would like to attend training courses in other fields (see Chart 7). 


\section{Chart 7. R18. Which field of activity would be of most interest in training courses? $(N=988)$ - Multiple answer}

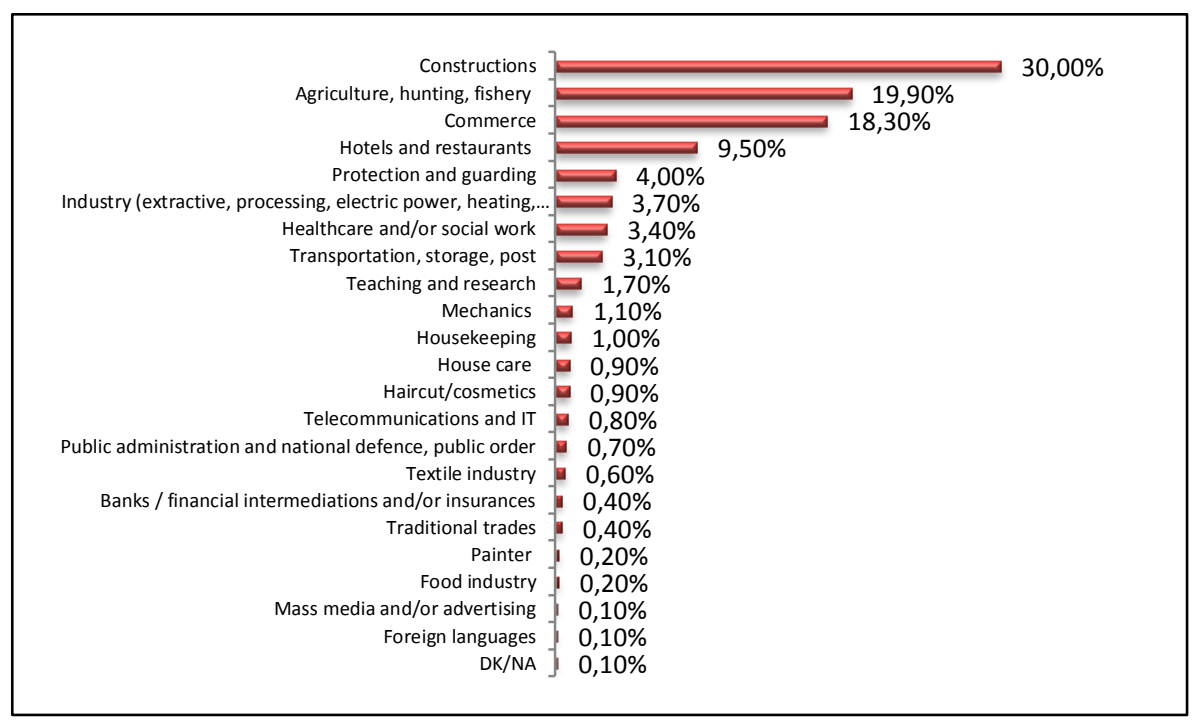

The top three areas of interest for men are constructions $(49.70 \%)$, commerce $(13.60 \%)$ and agriculture, hunting, fishery $(12.10 \%)$. The women showed interest for training courses in agriculture, hunting, fishery $(31.40 \%)$, commerce $(24.70 \%)$ and hotels and restaurants $(18.80 \%)$. (see Table 6)

Table 6. R18. Which area of activity would be of most interest in training courses? by gender - Multiple answer

\begin{tabular}{|l|l|l|}
\hline \multirow{2}{*}{ R18. Area of activity } & \multicolumn{2}{c|}{ S2. Gender of the respondent } \\
\cline { 2 - 3 } & \multicolumn{1}{|c|}{ Male } & \multicolumn{1}{c|}{ Female } \\
\hline Constructions & $49.70 \%$ & $2.00 \%$ \\
\hline Agriculture, hunting, fishery & $12.10 \%$ & $31.40 \%$ \\
\hline Commerce & $13.60 \%$ & $24.70 \%$ \\
\hline Hotels and restaurants & $2.90 \%$ & $18.80 \%$ \\
\hline Protection and guarding & $6.00 \%$ & $1.20 \%$ \\
\hline Industry (extractive, processing, electric power, heating, gases, water) & $4.80 \%$ & $2.20 \%$ \\
\hline Healthcare and/or social work & $0.50 \%$ & $7.70 \%$ \\
\hline Transportation, storage, post & $5.00 \%$ & $0.50 \%$ \\
\hline Teaching and research & $1.40 \%$ & $2.20 \%$ \\
\hline Mechanics & $1.90 \%$ & \\
\hline Housekeeping & & $2.50 \%$ \\
\hline House care & $0.20 \%$ & $2.00 \%$ \\
\hline Haircut/cosmetics & $0.20 \%$ & $2.00 \%$ \\
\hline Telecommunications and IT & $1.00 \%$ & $0.50 \%$ \\
\hline Public administration and national defence, public order & $0.90 \%$ & $0.50 \%$ \\
\hline
\end{tabular}




\begin{tabular}{|l|c|c|}
\hline \multirow{2}{*}{ R18. Area of activity } & \multicolumn{2}{c|}{ S2. Gender of the respondent } \\
\cline { 3 - 3 } & Male & Female \\
\hline Textile industry & $0.20 \%$ & $1.20 \%$ \\
\hline Banks / financial intermediations and/or insurances & & $1.00 \%$ \\
\hline Traditional trades & $0.70 \%$ & \\
\hline Painter & & $0.50 \%$ \\
\hline Food industry & & $0.50 \%$ \\
\hline Mass media and/or advertising & $0.20 \%$ & \\
\hline Foreign languages & $0.20 \%$ & \\
\hline NS/NR & $0.00 \%$ & $0.20 \%$ \\
\hline
\end{tabular}

In Bucharest-Ilfov, the top three areas of professional training, of interest for the respondents, are constructions, commerce, hotels and restaurants. In the other surveyed regions of development, the respondents also showed interest in constructions and commerce, but also in agriculture. (see Table 7)

Table 7. R18. Which area of activity would be of most interest in training courses? by region of development - Multiple answer

\begin{tabular}{|l|l|l|l|l|}
\hline \multirow{2}{*}{ R18. Area of activity } & \multicolumn{3}{|c|}{ Region of development } \\
\cline { 2 - 5 } & $\begin{array}{c}\text { Bucharest- } \\
\text { Ilfov }\end{array}$ & $\begin{array}{c}\text { South } \\
\text { Muntenia }\end{array}$ & $\begin{array}{c}\text { South- } \\
\text { West } \\
\text { Oltenia }\end{array}$ & South-East \\
\hline Constructions & $30.70 \%$ & $33.60 \%$ & $33.50 \%$ & $21.90 \%$ \\
\hline Commerce & $23.40 \%$ & $16.40 \%$ & $12.90 \%$ & $23.30 \%$ \\
\hline Hotels and restaurants & $19.00 \%$ & $9.40 \%$ & $4.90 \%$ & $9.30 \%$ \\
\hline Agriculture, hunting, fishery & $5.80 \%$ & $22.30 \%$ & $30.80 \%$ & $13.70 \%$ \\
\hline Healthcare and/or social work & $5.80 \%$ & $3.50 \%$ & $2.70 \%$ & $3.00 \%$ \\
\hline Protection and guarding & $4.40 \%$ & $2.80 \%$ & $4.60 \%$ & $4.80 \%$ \\
\hline Transportation, storage, post & $3.60 \%$ & $3.50 \%$ & $4.60 \%$ & $1.10 \%$ \\
\hline Haircut/cosmetics & $2.90 \%$ & $1.30 \%$ & $0.00 \%$ & $0.40 \%$ \\
\hline $\begin{array}{l}\text { Industry (extractive, processing, electric power, heating, } \\
\text { gases, water) }\end{array}$ & $2.20 \%$ & $2.20 \%$ & $3.80 \%$ & $6.30 \%$ \\
\hline Housekeeping & $0.70 \%$ & $1.90 \%$ & & $1.10 \%$ \\
\hline $\begin{array}{l}\text { Public administration and national defence, public } \\
\text { order }\end{array}$ & $0.70 \%$ & $1.30 \%$ & & $0.70 \%$ \\
\hline Textile industry & $0.70 \%$ & $0.30 \%$ & & $1.50 \%$ \\
\hline House care & $0.70 \%$ & & & $3.00 \%$ \\
\hline Mechanics & & $1.30 \%$ & $0.40 \%$ & $2.20 \%$ \\
\hline Traditional trades & & $0.90 \%$ & & $0.40 \%$ \\
\hline Telecommunications and IT & & $0.60 \%$ & $0.80 \%$ & $1.50 \%$ \\
\hline Food industry & & $0.60 \%$ & & \\
\hline Teaching and research & & $0.30 \%$ & $0.80 \%$ & $5.20 \%$ \\
\hline Banks / financial intermediations and/or insurances & & $0.30 \%$ & $0.40 \%$ & $0.70 \%$ \\
\hline Foreign languages & & $0.30 \%$ & & \\
\hline Painter & & & & $0.70 \%$ \\
\hline Mass media and/or advertising & & & & $0.40 \%$ \\
\hline NS/NR & & & $0.40 \%$ \\
\hline
\end{tabular}


In the field of agriculture, most respondents would like to attend training courses in animal husbandry $(73.20 \%)$ and plant culture $(65.60 \%)$. In Bucharest-Ilfov we noticed the lowest number of respondents interested to attend training courses in agriculture, hunting and fishery (19). In constructions, the trade of brick layer-stonemason-plasterer was indicated by $80.30 \%$ of the respondents. In commerce and services, the many of the respondents showed interest in the position of commercial worker $(62.90 \%)$, while in the food industry, most respondents would like to be qualified as bakers $(65.30 \%)$. Of the respondents willing to be qualified in the textile industry, $85.60 \%$ would like the job of textile products maker. A proportion of $61.40 \%$ of the respondents interested to attend training courses in forestry, wood exploitation and processing, would choose a training course for nursery and green areas workers. A proportion of $48.60 \%$ of the respondents interested to attend training courses in tourism, hotels and restaurants, would select a cook training course. A proportion of $22 \%$ of the respondents interested to attend training courses in other areas of activity than the mentioned ones, indicated a course for cauldron maker.

Table 8. R19. If you were to attend a free training course, which trade would you choose - Multiple answer

\begin{tabular}{|c|c|c|c|c|c|c|c|c|c|c|c|}
\hline & \multicolumn{8}{|c|}{ Region of development } & \multirow{2}{*}{\multicolumn{2}{|c|}{ Total }} \\
\hline & & \multicolumn{2}{|c|}{ Bucharest-Ilfov } & \multicolumn{2}{|c|}{ South Muntenia } & \multicolumn{2}{|c|}{$\begin{array}{l}\text { South-West } \\
\text { Oltenia }\end{array}$} & \multicolumn{2}{|c|}{ South-East } & & \\
\hline $\begin{array}{c}\text { Sector } \\
\text { of activity }\end{array}$ & Trade & $\begin{array}{l}\text { Number of } \\
\text { ansuers }\end{array}$ & $\begin{array}{l}\text { \% of total } \\
\text { respondents }\end{array}$ & $\begin{array}{c}\text { Number of } \\
\text { answers }\end{array}$ & $\begin{array}{l}\text { \% of total } \\
\text { respondents }\end{array}$ & $\begin{array}{l}\text { Number of } \\
\text { ansuers }\end{array}$ & $\begin{array}{l}\text { \% of total } \\
\text { respondents }\end{array}$ & $\begin{array}{c}\text { Number of } \\
\text { answers }\end{array}$ & $\begin{array}{l}\% \text { of total } \\
\text { respondents }\end{array}$ & $\begin{array}{c}\text { Number of } \\
\text { answers }\end{array}$ & $\begin{array}{l}\text { \% of total } \\
\text { respondents }\end{array}$ \\
\hline \multirow{10}{*}{$\begin{array}{l}\text { Agriculture, } \\
\text { forestry, } \\
\text { fishing }\end{array}$} & $\begin{array}{l}\text { Animal husbandry } \\
\text { worker }\end{array}$ & 9 & $47.40 \%$ & 97 & $71.90 \%$ & 89 & $75.40 \%$ & 65 & $78.30 \%$ & 260 & $73.20 \%$ \\
\hline & Plant crops worker & 10 & $52.60 \%$ & 78 & $57.80 \%$ & 91 & $77.10 \%$ & 54 & $65.10 \%$ & 233 & $65.60 \%$ \\
\hline & Fruitgrower & 5 & $26.30 \%$ & 50 & $37.00 \%$ & 81 & $68.60 \%$ & 19 & $22.90 \%$ & 155 & $43.70 \%$ \\
\hline & Vineyard grower & 4 & $21.10 \%$ & 40 & $29.60 \%$ & 71 & $60.20 \%$ & 15 & $18.10 \%$ & 130 & $36.60 \%$ \\
\hline & Horticulture worker & 2 & $10.50 \%$ & 22 & $16.30 \%$ & 46 & $39.00 \%$ & 9 & $10.80 \%$ & 79 & $22.30 \%$ \\
\hline & $\begin{array}{l}\text { Agro-tourism } \\
\text { worker }\end{array}$ & 5 & $26.30 \%$ & 9 & $6.70 \%$ & 35 & $29.70 \%$ & 8 & $9.60 \%$ & 57 & $16.10 \%$ \\
\hline & $\begin{array}{l}\text { Agricultural } \\
\text { technician }\end{array}$ & 8 & $42.10 \%$ & 26 & $19.30 \%$ & 26 & $22.00 \%$ & 11 & $13.30 \%$ & 71 & $20.00 \%$ \\
\hline & Fishery worker & 3 & $15.80 \%$ & 2 & $1.50 \%$ & 8 & $6.80 \%$ & 6 & $7.20 \%$ & 19 & $5.40 \%$ \\
\hline & Other & 1 & $530 \%$ & 2 & $1.50 \%$ & 0 & $0.00 \%$ & 0 & $0.00 \%$ & 3 & $0.80 \%$ \\
\hline & Total respondents & 19 & & 135 & & 118 & & 83 & & 355 & \\
\hline \multirow{7}{*}{ Constructions } & $\begin{array}{l}\text { Brick layer- } \\
\text { stonemason-plaster }\end{array}$ & 49 & $79.00 \%$ & 113 & $77.40 \%$ & 95 & $87.20 \%$ & 74 & $77.90 \%$ & 331 & $80.30 \%$ \\
\hline & $\begin{array}{l}\text { Painter-gypsum } \\
\text { worker-wallpaper } \\
\text { worker }\end{array}$ & 57 & $91.90 \%$ & 91 & $62.30 \%$ & 97 & $89.00 \%$ & 40 & $42.10 \%$ & 285 & $69.20 \%$ \\
\hline & $\begin{array}{l}\text { Carpenter / joiner- } \\
\text { floorer }\end{array}$ & 55 & $88.70 \%$ & 88 & $60.30 \%$ & 89 & $81.70 \%$ & 40 & $42.10 \%$ & 272 & $66.00 \%$ \\
\hline & Crane operator & 24 & $38.70 \%$ & 32 & $21.90 \%$ & 42 & $38.50 \%$ & 12 & $12.60 \%$ & 110 & $26.70 \%$ \\
\hline & Tiles, mosaic layer & 45 & $72.60 \%$ & 74 & $50.70 \%$ & 90 & $82.60 \%$ & 30 & $31.60 \%$ & 239 & $58.00 \%$ \\
\hline & Other & 19 & $30.60 \%$ & 28 & $19.20 \%$ & 12 & $11.00 \%$ & 18 & $18.90 \%$ & 77 & $18.70 \%$ \\
\hline & Total respondents & 62 & & 146 & & 109 & & 95 & & 412 & \\
\hline \multirow{7}{*}{$\begin{array}{l}\text { Commerce } \\
\text { and services }\end{array}$} & Commercial worker & 74 & $72.50 \%$ & 72 & $46.80 \%$ & 65 & $72.20 \%$ & 77 & $68.80 \%$ & 288 & $62.90 \%$ \\
\hline & Seller, food stuff & 58 & $56.90 \%$ & 53 & $34.40 \%$ & 33 & $36.70 \%$ & 61 & $54.50 \%$ & 205 & $44.80 \%$ \\
\hline & $\begin{array}{l}\text { Hair stylist/haircut/ } \\
\text { manicure/pedicure }\end{array}$ & 42 & $41.20 \%$ & 57 & $37.00 \%$ & 21 & $23.30 \%$ & 32 & $28.60 \%$ & 152 & $33.20 \%$ \\
\hline & Bootmaker & 6 & $5.90 \%$ & 4 & $2.60 \%$ & 0 & $0.00 \%$ & 18 & $16.10 \%$ & 28 & $6.10 \%$ \\
\hline & Security agent & 23 & $22.50 \%$ & 63 & $40.90 \%$ & 23 & $25.60 \%$ & 42 & $37.50 \%$ & 151 & $33.00 \%$ \\
\hline & Other & 5 & $4.90 \%$ & 5 & $3.20 \%$ & 0 & $0.00 \%$ & 3 & $2.70 \%$ & 13 & $2.80 \%$ \\
\hline & Total respondents & 102 & & 154 & & 90 & & 112 & & 458 & \\
\hline
\end{tabular}




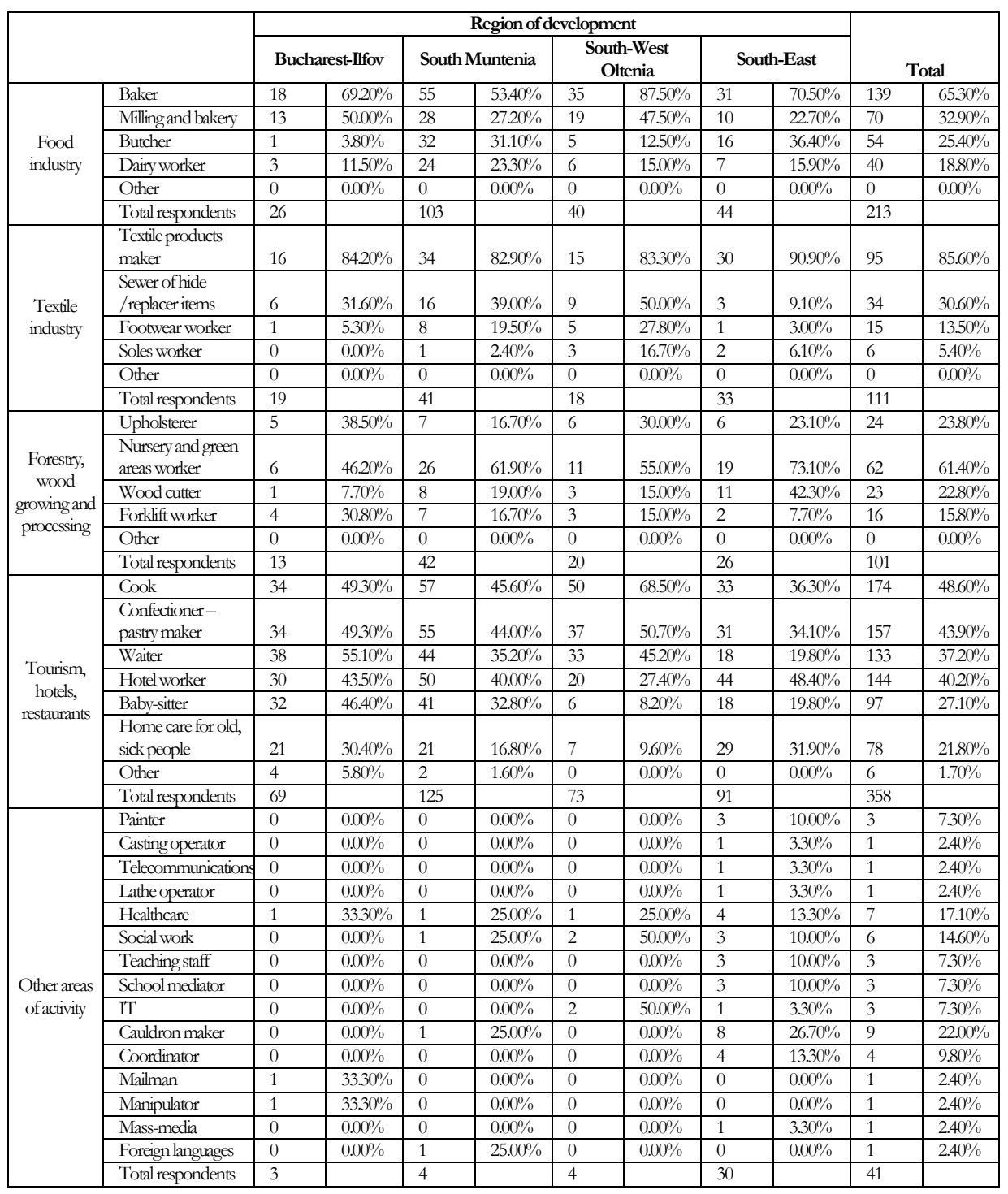

The respondents, out of local authority who have knowledge of occupational programs mentioned most often the training courses (44.40\%), mentioned generically. The actions organised by the employment agencies were mentioned by $40.70 \%$ of the respondents, followed by the Job exchange $(16.70 \%)$ and Employment caravan $(14.80 \%)$.

Asked of the occupational programs and actions, the local people of the target communities who said that they know of such actions, mentioned on the top four 
positions the programs already confirmed by the local authorities (see Table 9). They mentioned first the training courses $(39.50 \%)$, followed by the actions organised by the employment agencies (38.30\%), by the Job exchange (19.80\%) and by the Employment caravan $(8.60 \%)$.

Table 9: MS3. Occupational programs/actions known by the respondentsmultiple answer

\begin{tabular}{|c|c|c|}
\hline \multirow[b]{2}{*}{ Programs } & \multicolumn{2}{|c|}{ Answers } \\
\hline & $\begin{array}{l}\text { Local authorities } \\
\qquad(\mathrm{N}=54)\end{array}$ & $\begin{array}{l}\text { Local people } \\
\quad(\mathrm{N}=81)\end{array}$ \\
\hline Training courses & $44.40 \%$ & $39.50 \%$ \\
\hline ANOFM/AJOFM & $40.70 \%$ & $38.30 \%$ \\
\hline Job exchange & $16.70 \%$ & $19.80 \%$ \\
\hline Employment caravan & $14.80 \%$ & $8.60 \%$ \\
\hline Adds & $7.40 \%$ & \\
\hline Social canteen/lunch tickets & $5.60 \%$ & \\
\hline Billboards & $3.70 \%$ & \\
\hline Construction of a factory & $3.70 \%$ & \\
\hline $\begin{array}{l}\text { Counselling centre for parents and } \\
\text { children/professional guidance }\end{array}$ & $3.70 \%$ & \\
\hline School after school & $3.70 \%$ & \\
\hline Training courses provided by the town hall & $1.90 \%$ & $3.70 \%$ \\
\hline Courses through the EU & & $3.70 \%$ \\
\hline Roma alliance & & $2.50 \%$ \\
\hline Second opportunity & $1.90 \%$ & \\
\hline Sportive activities & $1.90 \%$ & \\
\hline Cultural activities & $1.90 \%$ & \\
\hline Healthcare activities & $1.90 \%$ & \\
\hline By phone & $1.90 \%$ & \\
\hline Entrepreneurship & & 1.20 \\
\hline NS/NR & & $17.30 \%$ \\
\hline Total & $155.60 \%$ & $134.60 \%$ \\
\hline
\end{tabular}

The interviewed representatives of the local authorities said that most beneficiaries of these programs or actions are Roma people $(92.3 \%$ of the mentioned programs, 26 cases in all). A respondent spoke of training courses in 2012-2013, attended by 80 Roma people, while another respondent remembered of training courses hosted by ANOJFM attended by 4 Roma people. The respondents also mentioned the locations where the occupational courses took place: Galați, Tecuci, Prahova, Tulcea, Viziru, Urziceni and Jilava. From the descriptions of the people who mentioned the location of 
the courses, we found out that in Urziceni there was an action for the beneficiaries of the MGI, while in the other locations the programs addressed the Roma people (see Table 10).

The interviewed local people consider that the occupational programs and actions address the Roma people ( 9 cases), the young people $(2$ cases), or the unemployed (one case). In terms of period when these programs/actions took place, 9 local people mentioned the years 2007, 2008, 2011, 2013, 2014, as well as the annual programs running in Galați. The locations mentioned by the local people are: București, Galați, Alexandria, Vălenii de Munte, Constanța, Medgidia, Târgoviște, Focșani, Tulcea, Buzău, Câmpulung Muscel. We noticed that in Galați, Alexandria and Focșani there were actions addressing the Roma people, while in Vălenii de Munte there were actions addressing the young people (see Table 11).

Table 10: MS3. Locations where occupational programs/actions took place, known by the representatives of the local authorities, by type of beneficiary

\begin{tabular}{|l|c|c|c|c|c|c|}
\multirow{3}{*}{ MS3.Beneficiaries } & \multicolumn{7}{|c|}{ Location } \\
\cline { 2 - 7 } & Galati & Tecuci & Prahova & Viziru & Urziceni & Jilava \\
\cline { 2 - 7 } & Count & Count & Count & Count & Count & Count \\
\hline Roma people & 1 & 1 & 1 & 1 & 0 & 1 \\
\hline MGI beneficiary & 0 & 0 & 0 & 0 & 1 & 0 \\
\hline
\end{tabular}

Table 11: MS2. Locations where occupational programs/actions took place, known by local people, by type of beneficiary

\begin{tabular}{|l|c|c|c|c|}
\hline \multirow{2}{*}{ MS2. Beneficiaries } & \multicolumn{4}{|c|}{ Location } \\
\cline { 2 - 5 } & $\begin{array}{c}\text { Galati } \\
\text { Count }\end{array}$ & $\begin{array}{c}\text { Alexandria } \\
\text { Count }\end{array}$ & $\begin{array}{c}\text { Valenii de Munte } \\
\text { Count }\end{array}$ & $\begin{array}{c}\text { Focsani } \\
\text { Count }\end{array}$ \\
\hline Roma people & 1 & 1 & 0 & 1 \\
\hline Young people & 0 & 0 & 1 & 0 \\
\hline
\end{tabular}

The interviews showed that AJOFM Galați organises each year occupational actions, but the results are rather poor. The results also show the organisation of the Job exchange in Prahova, in 2012-2013, but there were no Roma people employed thereafter. At the same time, the Job exchange organised in Jilava helped MCI beneficiaries to be employed. In terms of results of the occupational programs, the representatives of the local authorities mentioned the presents and the money aid given to the Roma people within the Employment caravan and of the training programs. The respondents evaluated as "satisfactory" the results of most types of occupational programs mentioned by them (see Table 12).

The interviewed local people evaluated the professional formation courses as being discriminating and without materialising in actual jobs (see Table 13). 
Intervention in Roma communities. Participation in formation activities $\mid 5$

Table 12: MS3. Results of the occupational programs/actions, known by the representatives of the local authorities - Multiple answer

\begin{tabular}{|l|c|c|c|c|c|c|c|}
\hline \multirow{2}{*}{ Results of the programs } & \multicolumn{7}{|c|}{ Programs } \\
\cline { 2 - 9 } & $\begin{array}{c}\text { ANOFM/ } \\
\text { AJOFM }\end{array}$ & Billboards & Adds & Phone & $\begin{array}{c}\text { Training } \\
\text { courses }\end{array}$ & $\begin{array}{c}\text { Job } \\
\text { exchange }\end{array}$ & $\begin{array}{c}\text { Employment } \\
\text { caravan }\end{array}$ \\
\hline Satisfactory results & 2 & 2 & 2 & 1 & 2 & 0 & 0 \\
\hline $\begin{array}{l}\text { The Roma people refused } \\
\text { the jobs offered by AJOFM }\end{array}$ & 1 & 0 & 0 & 0 & 1 & 0 & 0 \\
\hline No employment materialised & 1 & 0 & 0 & 0 & 2 & 1 & 1 \\
\hline Poor results & 1 & 0 & 0 & 0 & 2 & 1 & 2 \\
\hline Jobs resulted & 1 & 0 & 0 & 0 & 1 & 1 & 1 \\
\hline $\begin{array}{l}\text { The Roma people received } \\
\text { presents and money aids }\end{array}$ & 0 & 0 & 0 & 0 & 4 & 1 & 3 \\
\hline $\begin{array}{l}\text { The training courses are } \\
\text { according to labour market } \\
\text { requirements }\end{array}$ & 0 & 0 & 0 & 0 & 1 & 0 & 1 \\
\hline Very good results & 0 & 0 & 0 & 0 & 1 & 0 & 0 \\
\hline
\end{tabular}

Table 13: MS2. Results of the occupational programs/actions, known by local people - Multiple answer

\begin{tabular}{|c|c|c|c|c|c|c|}
\hline \multirow[b]{2}{*}{ Results of the programs } & \multicolumn{6}{|c|}{ Programs } \\
\hline & AJOFM & $\begin{array}{c}\text { Job } \\
\text { exchange }\end{array}$ & $\begin{array}{c}\text { Employment } \\
\text { caravan }\end{array}$ & $\begin{array}{l}\text { Training } \\
\text { courses }\end{array}$ & $\begin{array}{c}\text { Town } \\
\text { hall help }\end{array}$ & $\begin{array}{l}\text { Courses } \\
\text { through } \\
\text { the EU }\end{array}$ \\
\hline No employment materialised & 1 & 0 & 1 & 6 & 2 & 0 \\
\hline The participants were not paid & 0 & 0 & 0 & 2 & 1 & 0 \\
\hline $\begin{array}{l}\text { The outcome was not } \\
\text { satisfactory }\end{array}$ & 2 & 1 & 0 & 0 & 0 & 0 \\
\hline $\begin{array}{l}\text { The Roma people did not } \\
\text { attend }\end{array}$ & 0 & 0 & 0 & 2 & 0 & 0 \\
\hline Qualification diploma provided & 0 & 0 & 0 & 1 & 0 & 0 \\
\hline Very good results & 0 & 0 & 0 & 2 & 0 & 0 \\
\hline They discriminate & 1 & 1 & 0 & 3 & 0 & 1 \\
\hline The jobs are too poorly paid & 1 & 0 & 0 & 1 & 0 & 0 \\
\hline $\begin{array}{l}\text { The people are not interested in } \\
\text { information }\end{array}$ & 0 & 0 & 1 & 1 & 1 & 0 \\
\hline The training courses are useful & 1 & 0 & 0 & 2 & 0 & 0 \\
\hline
\end{tabular}


About half of the representatives of the local authorities interviewed in the four regions of development stated that they know of occupational programs. On South-West Oltenia, $42.90 \%$ of the respondents said that they know of such programs (see Table 14).

Table 14. MS2. Do you know occupational programs/actions? by region of development - Local authorities

\begin{tabular}{|c|c|c|c|c|c|}
\hline & \multicolumn{4}{|c|}{ Region of development } & \multirow[b]{2}{*}{ Total } \\
\hline & $\begin{array}{l}\text { Bucharest- } \\
\text { Ilfov }\end{array}$ & $\begin{array}{c}\text { South } \\
\text { Muntenia }\end{array}$ & $\begin{array}{l}\text { South-West } \\
\text { Oltenia }\end{array}$ & $\begin{array}{l}\text { South- } \\
\text { East }\end{array}$ & \\
\hline Yes & $50.00 \%$ & $50.00 \%$ & $42.90 \%$ & $51.60 \%$ & $48.7 \%$ \\
\hline Do not know & $50.00 \%$ & $47.60 \%$ & $57.10 \%$ & $45.20 \%$ & $49.60 \%$ \\
\hline NR & & $2.40 \%$ & & $3.20 \%$ & $1.70 \%$ \\
\hline
\end{tabular}

Most representatives of the local authorities interviewed in Bucharest-Ilfov region of development, said that they have heard of training courses $(25.00 \%)$ and of the Employment caravan (18.80\%). In South Muntenia region of development, $33.30 \%$ of the respondents mentioned the training courses, while $14.30 \%$ mentioned the actions of the employment agencies. In South-West Oltenia region of development, $21.40 \%$ of the respondents mentioned the programs of the employment agencies, and $14.30 \%$ mentioned the training courses. The actions of the employment agencies were also mentioned by $28.10 \%$ of the respondents from South-East region of development (see Table 15).

Table 15. MS3. Occupational programs/actions known by the representatives of the local authorities, by region of development - Multiple answer

\begin{tabular}{|l|c|c|c|c|}
\hline & \multicolumn{4}{|c|}{ Region of development } \\
\cline { 2 - 5 } & $\begin{array}{c}\text { Bucharest- } \\
\text { Ilfov }\end{array}$ & $\begin{array}{c}\text { South } \\
\text { Muntenia }\end{array}$ & $\begin{array}{c}\text { South-West } \\
\text { Oltenia }\end{array}$ & South-East \\
\hline Training courses & $25.00 \%$ & $33.30 \%$ & $14.30 \%$ & $6.20 \%$ \\
\hline Employment caravan & $18.80 \%$ & $7.10 \%$ & $3.60 \%$ & $3.10 \%$ \\
\hline ANOFM/AJOFM & $6.20 \%$ & $14.30 \%$ & $21.40 \%$ & $28.10 \%$ \\
\hline Job exchange & $6.20 \%$ & $11.90 \%$ & $3.60 \%$ & $6.20 \%$ \\
\hline Adds & $6.20 \%$ & & $3.60 \%$ & $6.20 \%$ \\
\hline $\begin{array}{l}\text { Social canteen/lunch } \\
\text { tickets }\end{array}$ & & $2.40 \%$ & $3.60 \%$ & $3.10 \%$ \\
\hline $\begin{array}{l}\text { Counselling centre for } \\
\text { parents and children/ } \\
\text { professional guidance }\end{array}$ & & $2.40 \%$ & & \\
\hline Building a factory & & $2.40 \%$ & & $3.60 \%$ \\
\hline $\begin{array}{l}\text { Training courses provided } \\
\text { by the town hall }\end{array}$ & & & & $3.10 \%$ \\
\hline School after school & & & & \\
\hline
\end{tabular}




\begin{tabular}{|l|c|c|c|c|}
\hline \multirow{2}{*}{} & \multicolumn{3}{|c|}{ Region of development } \\
\cline { 2 - 5 } & $\begin{array}{c}\text { Bucharest- } \\
\text { Ilfov }\end{array}$ & $\begin{array}{c}\text { South } \\
\text { Muntenia }\end{array}$ & $\begin{array}{c}\text { South-West } \\
\text { Oltenia }\end{array}$ & South-East \\
\hline Billboards & & & & $6.20 \%$ \\
\hline Second chance & & & & $3.10 \%$ \\
\hline Sport activities & & & & $3.10 \%$ \\
\hline Cultural activities & & & & $3.10 \%$ \\
\hline Healthcare activities & & & & $3.10 \%$ \\
\hline By phone & & & & $3.10 \%$ \\
\hline
\end{tabular}

In terms of results of the occupational programs, they were evaluated as being poor in each region of development, although jobs resulted, and some results were evaluated as satisfactory (see Table 16).

Table 16. MS3. Results of the occupational programs/actions known by the representatives of the local authorities, by region of development - Multiple answer

\begin{tabular}{|l|l|l|l|l|}
\hline \multirow{2}{*}{ Results } & \multicolumn{4}{|c|}{ Region of development } \\
\cline { 2 - 5 } & $\begin{array}{c}\text { Bucharest- } \\
\text { Ilfov }\end{array}$ & $\begin{array}{c}\text { South } \\
\text { Muntenia }\end{array}$ & $\begin{array}{c}\text { South-West } \\
\text { Oltenia }\end{array}$ & $\begin{array}{c}\text { South- } \\
\text { East }\end{array}$ \\
\cline { 2 - 5 } & \multicolumn{4}{|c|}{ Number of respondents } \\
\hline Poor results & 2 & 1 & 1 & 1 \\
\hline $\begin{array}{l}\text { The Roma people received gifts and money } \\
\text { aids }\end{array}$ & 2 & 1 & 0 & 1 \\
\hline No employments & 1 & 1 & 0 & 1 \\
\hline People were employed & 1 & 1 & 0 & 1 \\
\hline $\begin{array}{l}\text { The training courses are not according to } \\
\text { market requirements }\end{array}$ & 1 & 0 & 0 & 0 \\
\hline Satisfactory results & 0 & 1 & 1 & 2 \\
\hline $\begin{array}{l}\text { The Roma people turned down the jobs } \\
\text { offered by AjOFM }\end{array}$ & 0 & 1 & 0 & 0 \\
\hline Very good results & 0 & 0 & 1 & 0 \\
\hline Total & 4 & 6 & 3 & 5 \\
\hline
\end{tabular}

Most interviewed representatives of the local authorities agree that supporting the creation of jobs for Roma people would increase their opportunities of insertion on the labour market (78.90\%). The next measure about which most respondents agree totally or partially, that it would be to the benefit of the Roma people, is the development of training programs for basic qualifications $(87.80 \%)$. A proportion of $19.30 \%$ of the respondents disagree totally or partially with the fact that running specific measures for the vocational profile of the Roma people would help them integrate on the labour market. Seven respondents proposed different measures able to support the insertion of the Roma people on the labour market: guiding the pupils towards professional schools, counselling the adult people, training on the job, promotion of the artistic traditions and creation of new jobs. 
A proportion of $54 \%$ of the interviewed representatives of the local authorities, consider that the education and professional qualification of the Roma people is adequate to the current requirements of the labour market, while $42 \%$ do not agree with this statement.

Of the people who consider that the education and professional qualification of the Roma people is not adequate to the current requirements of the labour market, $56.20 \%$ propose, as solutions for this situation, the professional qualification/requalification, $20.80 \%$ education of the children, $12.50 \%$ continuation of the studies, as well as other educational measures, enhancing the interest of the Roma people, job creation and provision of financial support.

A proportion of $59 \%$ of the representatives of the local authorities stated that they know the training requirements in the county. Of them, most consider that training courses in constructions are necessary $(79.40 \%$ ), while $38.20 \%$ of the respondents knowing the training requirements in their county, consider that training courses in agriculture are necessary, $36.80 \%$ propose training courses as commercial agent and $16.20 \%$ support training courses for the textile industry. The other qualifications that would be necessary, mentioned by less than $15 \%$ of the respondents are: security agent, hair stylist, plumber, car mechanic, driver, janitor, processing industry, healthcare, transportation, natural resources and environmental protection, confectioner/pastry worker, education, fiddler, crafts, bootmaker, homecare for old people.

The representatives of the local authorities from South West Oltenia, support most of all, compared to the other regions of development, as measures for the insertion of the Roma people, the adoption of measures specific to the vocational profile of the Roma people, running programs for the development of the basic qualifications, creating occupations and jobs function of the capacities of the Roma people, supporting the practice of specific Roma trades. In Bucharest-Ilfov, the respondents believe least in the measure of developing new occupations for the Roma, as measure of social insertion $(62.40 \%$ ), while in South Muntenia are the fewest respondents supporting the traditional Roma crafts $(61.90 \%)$.

In South Muntenia region of development, most respondents consider that the education and professional qualification of the Roma people are adequate to labour market requirements $(61.90 \%$ ), while in Bucharest-Ilfov just $25.00 \%$ of the respondents consider that the professional training of the Roma people fits the requirements of the employers

The representatives of the local authorities, from all surveyed regions of development, consider that the education and professional training of the Roma people can become more adequate to labour market requirements by the qualification or requalification of the Roma people and by the education of the Roma children.

The representatives of the local authorities from the four surveyed regions of development consider that the constructions are the field with the highest demand for training. In Bucharest-Ilfov $43.80 \%$ of the respondents consider that people trained in commercial activities are sought in that county. A proportion of $11.90 \%$ of the respondents from South Muntenia consider that second to constructions, people 
trained in agriculture and textile industry are sought, while $42.90 \%$ of the respondents from South West Oltenia consider that there is demand for qualification in agriculture. The respondents from South East rank constructions first, followed by the demand for commercial workers $(25.00 \%)$ (see Table 17).

Table 17. MS9. Please enumerate the most sought qualifications in the county, by region of development - Multiple answer

\begin{tabular}{|l|l|l|l|l|}
\hline \multirow{2}{*}{ Training } & \multicolumn{4}{c|}{ Region of development } \\
\cline { 2 - 5 } & $\begin{array}{c}\text { Bucharest- } \\
\text { Ilfov }\end{array}$ & $\begin{array}{c}\text { South } \\
\text { Muntenia }\end{array}$ & $\begin{array}{c}\text { South-West } \\
\text { Oltenia }\end{array}$ & $\begin{array}{c}\text { South- } \\
\text { East }\end{array}$ \\
\hline Constructions & $56.20 \%$ & $45.20 \%$ & $60.70 \%$ & $28.10 \%$ \\
\hline Commercial worker & $43.80 \%$ & $4.80 \%$ & $28.60 \%$ & $25.00 \%$ \\
\hline Security agent & $31.20 \%$ & $4.80 \%$ & & $6.20 \%$ \\
\hline Agriculture & $18.80 \%$ & $11.90 \%$ & $42.90 \%$ & $18.80 \%$ \\
\hline Textile worker/tailor & $12.50 \%$ & $11.90 \%$ & $3.60 \%$ & $9.40 \%$ \\
\hline Cosmetics, hair stylist & $6.20 \%$ & $7.10 \%$ & & $6.20 \%$ \\
\hline Janitor & $6.20 \%$ & $2.40 \%$ & & \\
\hline Plumber & & $7.10 \%$ & & $3.20 \%$ \\
\hline Car mechanic & & $4.80 \%$ & $3.60 \%$ & \\
\hline Processing industry & & $4.80 \%$ & & \\
\hline Healthcare & & $2.40 \%$ & & \\
\hline Transportation & & $2.40 \%$ & & \\
\hline confectioner/pastry worker & & $2.40 \%$ & & \\
\hline Fiddler & & $2.40 \%$ & & \\
\hline Craftsman & & $2.40 \%$ & & $3.10 \%$ \\
\hline Shoemaker & & $2.40 \%$ & & $3.10 \%$ \\
\hline Driver & & & $3.60 \%$ & $3.10 \%$ \\
\hline $\begin{array}{l}\text { Natural resources and environmental } \\
\text { protection }\end{array}$ & & & & \\
\hline Education & & & & \\
\hline Homecare for the elder & $6.20 \%$ & & & \\
\hline NS/NR & & & & \\
\hline
\end{tabular}

\section{Conclusions}

For most of the local respondents, it is extremely important to be honest in order to have success in life (47\%), while for just $22 \%$ of them it is highly important to learn continuously. The faculty is important for $57 \%$ of the respondents, while the middleclass education is important for $77 \%$ of the respondents. The professional training is important to acquire success, for $81 \%$ of the respondents. At the level of all surveyed regions of development, work is seen as source of income. A proportion of $49.30 \%$ of the respondents who graduated at most the middle school are romanized Roma, and $21.80 \%$ are ursari. A proportion of $68 \%$ of the respondents with secondary education are romanized Roma, and $16.40 \%$ are ursari. With faculty education, we noticed $22.20 \%$ ursari and $11.10 \%$ brick makers. A total of 614 respondents declared that they have no 
qualification, and the most frequent qualifications are in mechanics, plumbing and constructions, in all surveyed regions of development. A total of 355 interviewed local people said they never attended professional training courses, but $87.8 \%$ of the respondents would like to attend professional training courses, or to improve their skills, in the following period, if these courses are free and transportation is provided.

Of the respondents who would like to attend formation courses, 30\% would like to qualify in constructions, $19.90 \%$ in agriculture and $18.30 \%$ in commercial activities. The top three areas of interest for the men are constructions $(49.70 \%)$, commerce $(13.60 \%)$ and agriculture, hunting, and fishery $(12.10 \%)$. The women showed interest in attending training courses mainly in agriculture, hunting, and fishery $(31.40 \%)$, commerce $(24.70 \%)$ and hotels and restaurants $(18.80 \%)$. In Bucharest-Ilfov, the top three areas of professional formation of interest for the respondents are constructions, commerce and hotels and restaurants. In the other surveyed regions of development, the respondents also showed interest in constructions, commerce, but also in agriculture.

A proportion of $50.60 \%$ of the local people who attended the survey are inactive on the labour market, of which $1.70 \%$ are retired people, $0.60 \%$ were going to integrate on the labour market after the period of survey, being students or freshly graduates. A proportion of $12.70 \%$ of the respondents are active and have a constant income (employees, company owners and self-employed). The sample also includes $36.70 \%$ people with occasional incomes (hired hands and agricultural workers). In BucharestIlfov there is the highest proportion of employees $(20.30 \%)$, compared to the proportion of employees in other regions of development. In South-Muntenia, there is the highest proportion of people working in the household $(22.30 \%)$, compared to the other three surveyed regions of development, and just $9 \%$ employed people among the respondents. In South West Oltenia, just $2.30 \%$ of the respondents are employed, the main income coming, in this region, from occasional non-agricultural activities $(14.00 \%)$. In South East there is the highest proportion of people working by the day in non-agricultural activities $(21.20 \%)$, which is the main source of income in this region.

A proportion of $56 \%$ of the unemployed respondents said that they have been looking for a job in the last year. While in South Muntenia and South East regions of development, less than $60 \%$ of the respondents looked for a job during the past year, in South West Oltenia and Bucharest-Ilfov, over $77 \%$ of the respondents looked for a job during the past year, and $83.20 \%$ of the respondents looking for a job during the past year, said that they looked for a job asking friends, relatives or people they know. Relations are the source of getting a job for most respondents in every surveyed region of development. Most inactive respondents in the four surveyed regions of development claimed the lack of qualification, followed by the economic crisis, as major reasons why they did not get a job. While in Bucharest-Ilfor and South Muntenia, the top two solutions given by the respondents as alternative if they do not get a job, is the temporary employment and working in a lower qualification than they have, in South West Oltenia and South East, most respondents are willing to work for a determined period of time, or be less paid. In South East we find the highest proportion $(24.50 \%)$ of respondents willing to work for a wage up to 700 lei, compared to the situation in the other surveyed regions of development. In South West Oltenia, $77.60 \%$ of the respondents would for a wage of 701 to 1000 lei per month, the highest 
proportion with this option a mong all surveyed regions. Only in Bucharest-Ilfov, we find the highest proportion of respondents willing to work for a wage of 1001 to 1500 de lei.

The highest proportion of the local respondents who are employed, work in constructions $(28.70 \%$ ), while $12.60 \%$ work in agriculture and $12.60 \%$ work in commercial activities. A proportion of $45 \%$ of the employed respondents said that they have a labour contract on undetermined period, while $29 \%$ work with no form of contract.

\section{References}

Arpinte, D., Cace, S., Theotokatos, H., Koumalatsou, E. (2010). The social economy in European Union, Revista Calitatea Vieții, XXI(1-2), 137-160

Cace, S., (coord.) (2010). Social Economy in Europe, Bucureşti: Editura Expert

Cace, S. (coord), Arpinte D., Scoican A. (2010). Economia sociala in Romania. Două profiluri regionale [The Social Economy in Romania. Two regional profiles], Bucureşti: Editura Expert

Cace, S., Duminică, G., Preda, M. (coord.) (2005). Evaluarea programelor pentru comunitățile de romi din România, Agenția de Dezvoltare Comunitară Împreuna / UNDP

Cace, S., Nicolăescu, V., Scoican, A. (2010). Best Practices in Social Economy sector in Greece and other UE countries, București: Editura Expert

Cace, S. (coord.), Neagu, G., Raţ, C., Ivasiuc, A. (2013) Politici de incluæiune a romilor in statele membre ale Uniunii Europene. Studii de Strategie și Politici - SPOS.

Cace, S., Preoteasa, A.M., Tomescu, C., Stănescu, S. (2010). Legal si egal pe piața muncii pentru comunitătile de romi. Diagnoza factorilor care influențează nivelul de ocupare la populația de romi. [Legal and illegal on the labour market], Bucureşti: Editura Expert

Cace, S., Tomescu, C., Cojocaru, D. (2012). The role of religion in several Roma communities, Revista de cercetare si interventie socială, 36: 162-177

Caramihai, D.-M., Mocanu, M., Szekely, A., Oancea, M., Văduva, G. Analiza nevoilor de formare pentru persoanele din mediul rural, ANF

Ciutacu, C., Chivu. L (2007). Calitatea muncii și a ocupării forţei de muncă în România

Duminică, G., Cace, S., Arpinte, D., Ionescu, M., Iova, C., Sali, N. (2004). Politici de incluriune socială pentru grupurile vulnerabile. Cresterea accesului pe piața muncii.

Duminică, G., Ivasiuc, A. (2010). O școală pentru toți? Accesul copiilor romi la o educație de calitate. UNICEF. București: Vanemonde

Duminică, G., Preda, M. (2003). Accesul romilor pe piaţa muncii, Editura Cărţii de Agribusiness

Dumitrescu, A. L., P. Prisecaru (2012). Politici de ocupare și combaterea șomajului în Uniunea Europeană și România. Strategia de ocupare a UE şi reducere a şomajului, Revista de Economie Mondială, 4(2)

Fleck, G., Florea, I., Kiss, D., Rughiniş, C. (2008) Vino mai aproape. Inclužiunea şi exclužiunea romilor in societatea românească de aæi, București: Human Dynamics

Fecioru, B. (2008). Măsuri de îmbunătățire a Șanselor tinerilor pe piața muncii în Revista Calitatea Vieții 19(3-4): 317-317

Ionescu, M., Cace, S.(coord.), Cace, C., Dediu, M., Duminică, G. (2006). Employment Policies for Roma, Bucureşti: Editura Expert 
Ionescu, M., Stănescu, S., M. (2014). Politici publice pentru romi. Raport de evaluare a programelor naționale finantate de Uniunea Europeană pentru incluz̧iunea romilor, Bucureşti: Editura Pro Universitaria

Mihăilescu V. (2003). Evoluţia geografică a unui oraș - București, Editura Paideia

Moisă, F., Rostas, I. A., Tarnovschi, D., Stoian, I., Rădulescu, D., Andersen, T. S. (2013). Raportul societătii civile asupra implementării Strategiei Naționale de Integrare a Romilor și a Planului de Acţiune al Deceniului in România în 2012. Budapest: Decade of Roma Inclusion Secretariat Foundation

Paraschivei, L. (2012). Rata ocupării în România. Analiza de tip panel, in Revista de economie teoretică și aplicată 21(7): 11-22

Preda, M., Duminică, G., Moisă, F. Tânăr rom - caut loc de muncă, [Online] available on: http://www.agentiaimpreuna.ro/files/publicatii/5-tanar rom munca.pdf

Preoteasa, A. M. (2008). Fenomenul ocupării în România și dezvoltarea durabilă, in Calitatea Vieții (1-2): 53-69

Stanef, M. R. (2012). Creșterea ratei de participare a forței de muncă și reducerea șomajului structural în zonele rurale și urbane din Europa. Studiu de caz - România, in Revista de economie teoretică și aplicată, 19(3)

Stanescu, S., Cace, S. (2011). Alt fel de ocupare: Cererea de economie socială în regiunile de dez̧voltare București-Ilfor și Sud-Est. București: Editura Expert

Șerban, A. C. (2013). Politici publice care țintesc rigidităţile pieței forței de muncă, in Revista de economie teoretică și aplicată 20(2): 65-79

Tarnovschi D., Preoteasa, A.M., Şerban, M. (2012). Situația romilor în România, 2011. Între incluriune socială şi migrație. Raport de țară- România. Fundația Soros România

Toma, S., Fosztó, L. (2011). Spectrum. Cercetări sociale despre romi, Cluj-Napoca: ISPMN Publishing \& Kriterion

Vaughn, R. H. (2008). Manualul trainerului profesionist. Planificarea, livrarea și evaluarea programelor de instruire. București: CODECS

Zamfir, C. Zamfir, E. (coord.) (1993). Ţiganii: Între ignorare şi îngrijorare, Bucureşti: Editura Alternative 
Intervention in Roma communities. Participation in formation activities $\mid 67$

\section{Appendix: Profile of the Roma respondents from the target marginalized communities}

The study of the situation of the marginalized Roma communities from the development regions Bucharest-Ilfov, South Muntenia, South West Oltenia and South East, proceeded in June-August 2014, with a margin of error of $2.6 \%$, with a confidence level of $95 \%$. We conducted a total of 1072 interviews with inhabitants of these communities according to the following structure (see Table A): 153 interviews in Bucharest-Ilfov, 348 in South Muntenia, 265 in South West Oltenia and 306 in South East. The sample included $98.80 \%$ of the local people who declared to be Roma, $1.10 \%$ Romanian locals and one Serbian.

Table A. Q2. Ethnic group, by region of development and total

\begin{tabular}{|c|c|c|c|c|c|c|}
\hline \multirow{2}{*}{\multicolumn{2}{|c|}{ Ethnic group }} & \multicolumn{4}{|c|}{ Region of development } & \multirow{3}{*}{$\begin{array}{l}\text { Total } \\
12\end{array}$} \\
\hline & & \multirow{2}{*}{$\begin{array}{l}\begin{array}{l}\text { Bucharest- } \\
\text { Ilfov }\end{array} \\
6 \\
\end{array}$} & \multirow{2}{*}{$\begin{array}{c}\begin{array}{c}\text { South } \\
\text { Muntenia }\end{array} \\
2 \\
\end{array}$} & \multirow{2}{*}{$\begin{array}{c}\begin{array}{c}\text { South West } \\
\text { Oltenia }\end{array} \\
1\end{array}$} & \multirow{2}{*}{$\begin{array}{c}\begin{array}{c}\text { South } \\
\text { East }\end{array} \\
3\end{array}$} & \\
\hline Romanian & No. of respondents & & & & & \\
\hline & $\begin{array}{l}\% \text { of the Region of } \\
\text { development }\end{array}$ & $3.90 \%$ & $0.60 \%$ & $0.40 \%$ & $1.00 \%$ & $1.10 \%$ \\
\hline \multirow{2}{*}{$\begin{array}{l}\text { Roma / } \\
\text { Gypsy }\end{array}$} & No. of respondents & 147 & 345 & 264 & 303 & 1059 \\
\hline & $\begin{array}{l}\% \text { of the Region of } \\
\text { development }\end{array}$ & $96.10 \%$ & $99.10 \%$ & $99.60 \%$ & $99.00 \%$ & $\begin{array}{l}98.80 \\
\%\end{array}$ \\
\hline \multirow[t]{2}{*}{ Serbian } & No. of respondents & 0 & 1 & 0 & 0 & 1 \\
\hline & $\begin{array}{l}\% \text { of the Region of } \\
\text { development }\end{array}$ & $0.00 \%$ & $0.30 \%$ & $0.00 \%$ & $0.00 \%$ & $0.10 \%$ \\
\hline Total & No. of respondents & 153 & 348 & 265 & 306 & 1072 \\
\hline
\end{tabular}

We can see that 44 respondents stated to be Romanians at the 2011 Census (see Table B), compared to the 12 who stated to be Romanians (see Table A).

Table B. Q3. Ethnic affiliation stated at the 2011 Census, by region of development, and total

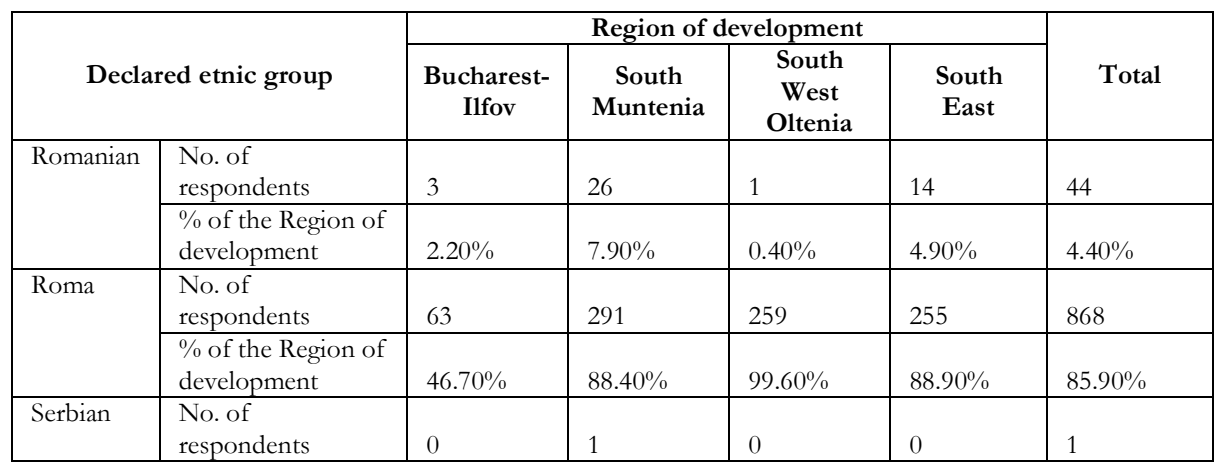




\begin{tabular}{|l|l|l|l|l|l|l|}
\hline \multirow{2}{*}{ Declared etnic group } & \multicolumn{3}{|c|}{ Region of development } & \multirow{2}{*}{ Total } \\
\cline { 2 - 6 } & $\begin{array}{c}\text { Bucharest- } \\
\text { Ilfov }\end{array}$ & $\begin{array}{c}\text { South } \\
\text { Muntenia }\end{array}$ & $\begin{array}{c}\text { South } \\
\text { West } \\
\text { Oltenia }\end{array}$ & $\begin{array}{c}\text { South } \\
\text { East }\end{array}$ & \\
\cline { 2 - 6 } & $\begin{array}{l}\text { \% of the Region of } \\
\text { development }\end{array}$ & $0.00 \%$ & $0.30 \%$ & $0.00 \%$ & $0.00 \%$ & $0.10 \%$ \\
\hline $\begin{array}{l}\text { I did not } \\
\text { participate }\end{array}$ & $\begin{array}{l}\text { No. of } \\
\text { respondents }\end{array}$ & 46 & 11 & 0 & 18 & 75 \\
\cline { 2 - 6 } & $\begin{array}{l}\text { \% of the Region of } \\
\text { development }\end{array}$ & $34.10 \%$ & $3.30 \%$ & $0.00 \%$ & $6.30 \%$ & $7.40 \%$ \\
\hline NS/NR & $\begin{array}{l}\text { No. of } \\
\text { respondents }\end{array}$ & 23 & 0 & 0 & 0 & 23 \\
\cline { 2 - 6 } & $\begin{array}{l}\text { \% of the Region of } \\
\text { development }\end{array}$ & $17.00 \%$ & $0.00 \%$ & $0.00 \%$ & $0.00 \%$ & $2.30 \%$ \\
\hline \multirow{2}{*}{ Total } & $\begin{array}{l}\text { No. of } \\
\text { respondents }\end{array}$ & 135 & 329 & 260 & 287 & 1011 \\
\hline
\end{tabular}

Most of the respondents stated by be Romanised Roma (54\%). 20.0\% of the respondents stated to be ursari (see Table C).

Table C. Q4. Roma line stated by the respondents, by region of development, and total

\begin{tabular}{|c|c|c|c|c|c|c|}
\hline \multirow{2}{*}{\multicolumn{2}{|c|}{ Roma line }} & \multicolumn{4}{|c|}{ Region of development } & \multirow[b]{2}{*}{ Total } \\
\hline & & $\begin{array}{l}\text { Bucharest- } \\
\text { Ilfov }\end{array}$ & $\begin{array}{c}\text { South } \\
\text { Muntenia }\end{array}$ & $\begin{array}{c}\text { South } \\
\text { West } \\
\text { Oltenia }\end{array}$ & $\begin{array}{l}\text { South } \\
\text { East }\end{array}$ & \\
\hline \multirow[t]{2}{*}{ Brick maker } & No. of respondents & 1 & 10 & 70 & 4 & 85 \\
\hline & $\begin{array}{l}\% \text { of the Region of } \\
\text { development }\end{array}$ & $0.70 \%$ & $2.90 \%$ & $26.40 \%$ & $1.40 \%$ & $8.10 \%$ \\
\hline \multirow[t]{2}{*}{ Rudar } & No. of respondents & 1 & 14 & 0 & 44 & 59 \\
\hline & $\begin{array}{l}\% \text { of the Region of } \\
\text { development }\end{array}$ & $0.70 \%$ & $4.00 \%$ & $0.00 \%$ & $15.30 \%$ & $5.60 \%$ \\
\hline \multirow{2}{*}{$\begin{array}{l}\text { Chimney } \\
\text { maker }\end{array}$} & No. of respondents & 0 & 9 & 0 & 17 & 26 \\
\hline & $\begin{array}{l}\% \text { of the Region of } \\
\text { development }\end{array}$ & $0.00 \%$ & $2.60 \%$ & $0.00 \%$ & $5.90 \%$ & $2.50 \%$ \\
\hline \multirow{2}{*}{$\begin{array}{l}\text { Bucket } \\
\text { maker }\end{array}$} & No. of respondents & 1 & 13 & 0 & 44 & 58 \\
\hline & $\begin{array}{l}\% \text { of the Region of } \\
\text { development }\end{array}$ & $0.70 \%$ & $3.80 \%$ & $0.00 \%$ & $15.30 \%$ & $5.50 \%$ \\
\hline \multirow[t]{2}{*}{ Ursar } & No. of respondents & 3 & 66 & 84 & 62 & 215 \\
\hline & $\begin{array}{l}\% \text { of the Region of } \\
\text { development }\end{array}$ & $2.00 \%$ & $19.10 \%$ & $31.70 \%$ & $21.50 \%$ & $20.40 \%$ \\
\hline \multirow{2}{*}{$\begin{array}{l}\text { Romanised } \\
\text { Roma }\end{array}$} & No. of respondents & 144 & 224 & 104 & 96 & 568 \\
\hline & $\begin{array}{l}\text { \% of the Region of } \\
\text { development }\end{array}$ & $94.10 \%$ & $64.70 \%$ & $39.20 \%$ & $33.30 \%$ & $54.00 \%$ \\
\hline \multirow[t]{2}{*}{ Silversmith } & No. of respondents & 1 & 0 & 0 & 0 & 1 \\
\hline & $\begin{array}{l}\% \text { of the Region of } \\
\text { development }\end{array}$ & $0.70 \%$ & $0.00 \%$ & $0.00 \%$ & $0.00 \%$ & $0.10 \%$ \\
\hline \multirow{2}{*}{$\begin{array}{l}\text { Cauldron } \\
\text { maker }\end{array}$} & No. of respondents & 0 & 1 & 0 & 0 & 1 \\
\hline & $\begin{array}{l}\text { \% of the Region of } \\
\text { development }\end{array}$ & $0.00 \%$ & $0.30 \%$ & $0.00 \%$ & $0.00 \%$ & $0.10 \%$ \\
\hline Sieve maker & No. of respondents & 0 & 0 & 0 & 2 & 2 \\
\hline
\end{tabular}




\begin{tabular}{|c|c|c|c|c|c|c|}
\hline & \multirow[b]{2}{*}{ Roma line } & \multicolumn{4}{|c|}{ Region of development } & \multirow[b]{2}{*}{ Total } \\
\hline & & $\begin{array}{l}\text { Bucharest- } \\
\text { Ilfov }\end{array}$ & $\begin{array}{c}\text { South } \\
\text { Muntenia }\end{array}$ & $\begin{array}{c}\text { South } \\
\text { West } \\
\text { Oltenia }\end{array}$ & $\begin{array}{l}\text { South } \\
\text { East }\end{array}$ & \\
\hline & $\begin{array}{l}\% \text { of the Region of } \\
\text { development }\end{array}$ & $0.00 \%$ & $0.00 \%$ & $0.00 \%$ & $0.70 \%$ & $0.20 \%$ \\
\hline \multirow[t]{2}{*}{ Laias } & No. of respondents & 0 & 3 & 7 & 2 & 12 \\
\hline & $\begin{array}{l}\% \text { of the Region of } \\
\text { development }\end{array}$ & $0.00 \%$ & $0.90 \%$ & $2.60 \%$ & $0.70 \%$ & $1.10 \%$ \\
\hline \multirow[t]{2}{*}{ Fiddler } & No. of respondents & 0 & 0 & 0 & 1 & 1 \\
\hline & $\begin{array}{l}\% \text { of the Region of } \\
\text { development }\end{array}$ & $0.00 \%$ & $0.00 \%$ & $0.00 \%$ & $0.30 \%$ & $0.10 \%$ \\
\hline \multirow[t]{2}{*}{ Tinker } & No. of respondents & 0 & 2 & 0 & 0 & 2 \\
\hline & $\begin{array}{l}\% \text { of the Region of } \\
\text { development }\end{array}$ & $0.00 \%$ & $0.60 \%$ & $0.00 \%$ & $0.00 \%$ & $0.20 \%$ \\
\hline \multirow[t]{2}{*}{ Tinsmith } & No. of respondents & 0 & 1 & 0 & 0 & 1 \\
\hline & $\begin{array}{l}\% \text { of the Region of } \\
\text { development }\end{array}$ & $0.00 \%$ & $0.30 \%$ & $0.00 \%$ & $0.00 \%$ & $0.10 \%$ \\
\hline \multirow[t]{2}{*}{ NS / NR } & No. of respondents & 2 & 3 & 0 & 16 & 21 \\
\hline & $\begin{array}{l}\% \text { of the Region of } \\
\text { development }\end{array}$ & $1.30 \%$ & $0.90 \%$ & $0.00 \%$ & $5.60 \%$ & $2.00 \%$ \\
\hline Total & No. of respondents & 153 & 346 & 265 & 288 & 1052 \\
\hline
\end{tabular}

$50.60 \%$ of the respondents are inactive on the labour market, including the retired people. $1.70 \%$ of the respondents are retired persons. $12.70 \%$ of the surveyed people are active on the labour market, including the employees, self-employed people and owners of companies. $36.70 \%$ of the respondents stated to work occasionally, including the people working in agriculture, who obtain occasional incomes from their work (see Table D).

Table D. SPM1. Occupational status, by region of development, and total $(\mathrm{N}=1068)$

\begin{tabular}{|l|l|l|l|l|l|}
\hline \multirow{2}{*}{ Occupational status } & \multicolumn{3}{|c|}{ Region of development } & \multirow{2}{*}{ Total } \\
\cline { 2 - 5 } & $\begin{array}{c}\text { Bucharest- } \\
\text { Ilfov }\end{array}$ & $\begin{array}{c}\text { South } \\
\text { Muntenia }\end{array}$ & $\begin{array}{c}\text { South West } \\
\text { Oltenia }\end{array}$ & South East & \\
\hline No occupation & $42.50 \%$ & $18.80 \%$ & $29.50 \%$ & $17.30 \%$ & $24.40 \%$ \\
\hline $\begin{array}{l}\text { Worker by the day / } \\
\text { occasional work (not in } \\
\text { agriculture) }\end{array}$ & $15.00 \%$ & $20.60 \%$ & $14.00 \%$ & $21.20 \%$ & $18.40 \%$ \\
\hline Household worker & $9.20 \%$ & $22.30 \%$ & $17.80 \%$ & $16.70 \%$ & $17.70 \%$ \\
\hline $\begin{array}{l}\text { Worker by the day / } \\
\text { occasional work in } \\
\text { agriculture }\end{array}$ & $2.00 \%$ & $16.80 \%$ & $32.20 \%$ & $13.70 \%$ & $17.60 \%$ \\
\hline Employee & $20.30 \%$ & $9.00 \%$ & $2.30 \%$ & $10.50 \%$ & $9.40 \%$ \\
\hline Registered unemployed & $2.60 \%$ & $5.80 \%$ & $0.00 \%$ & $7.80 \%$ & $4.50 \%$ \\
\hline $\begin{array}{l}\text { Self-employed in non- } \\
\text { agricultural activities, } \\
\text { freelancer, liberal and } \\
\text { artistic professions, PFA, } \\
\text { individual enterprise }\end{array}$ & $2.00 \%$ & & & & \\
\hline $\begin{array}{l}\text { Retired due to health } \\
\text { problems }\end{array}$ & $2.00 \%$ & $3.50 \%$ & $1.90 \%$ & $2.60 \%$ & $2.60 \%$ \\
\hline
\end{tabular}




\begin{tabular}{|l|l|l|l|l|l|}
\hline \multirow{2}{*}{ Occupational status } & \multicolumn{3}{|c|}{ Region of development } & \multirow{2}{*}{ Total } \\
\cline { 2 - 5 } & $\begin{array}{c}\text { Bucharest- } \\
\text { Ilfov }\end{array}$ & $\begin{array}{c}\text { South } \\
\text { Muntenia }\end{array}$ & $\begin{array}{c}\text { South West } \\
\text { Oltenia }\end{array}$ & South East & \\
\hline Receiver of VMG & $0.00 \%$ & $0.00 \%$ & $0.00 \%$ & $5.60 \%$ & $1.60 \%$ \\
\hline $\begin{array}{l}\text { Company owner / } \\
\text { administrator }\end{array}$ & $2.00 \%$ & $0.30 \%$ & $0.00 \%$ & $1.30 \%$ & $0.70 \%$ \\
\hline Farmer & $2.00 \%$ & $0.30 \%$ & $0.80 \%$ & $0.70 \%$ & $0.70 \%$ \\
\hline $\begin{array}{l}\text { pupil/student or recently } \\
\text { graduate }\end{array}$ & $0.70 \%$ & $0.30 \%$ & $0.40 \%$ & $1.00 \%$ & $0.60 \%$ \\
\hline Social aid & $0.00 \%$ & $0.00 \%$ & $0.40 \%$ & $0.00 \%$ & $0.10 \%$ \\
\hline $\begin{array}{l}\text { Pension from deceased } \\
\text { husband/wife }\end{array}$ & $0.00 \%$ & $0.30 \%$ & $0.00 \%$ & $0.00 \%$ & $0.10 \%$ \\
\hline
\end{tabular}

Most of the respondents stated that they have never been employed legally (69\%). In each surveyed region of development, most respondents stated that they never worked legally (see Table E).

Table E. SPM2. Legally employed, by region of development and total $(\mathrm{N}=831)$

\begin{tabular}{|c|c|c|c|c|c|}
\hline \multirow[b]{2}{*}{$\begin{array}{l}\text { Legally } \\
\text { employed }\end{array}$} & \multicolumn{4}{|c|}{ Region of development } & \multirow[b]{2}{*}{ Total } \\
\hline & $\begin{array}{l}\text { Bucharest- } \\
\text { Ilfov }\end{array}$ & $\begin{array}{c}\text { South } \\
\text { Muntenia }\end{array}$ & $\begin{array}{c}\text { South West } \\
\text { Oltenia }\end{array}$ & $\begin{array}{c}\text { South } \\
\text { East }\end{array}$ & \\
\hline Yes & $36.90 \%$ & $40.40 \%$ & $17.00 \%$ & $30.20 \%$ & $31.00 \%$ \\
\hline No & $63.10 \%$ & $59.60 \%$ & $83.00 \%$ & $69.80 \%$ & $69.00 \%$ \\
\hline
\end{tabular}

A higher proportion of men declared to have been employed legally $(37.10 \%)$ than women $(23 \%)$ (see Figure A).

Fig. A. SPM2. Legally employed people, by gender $(N=829)$

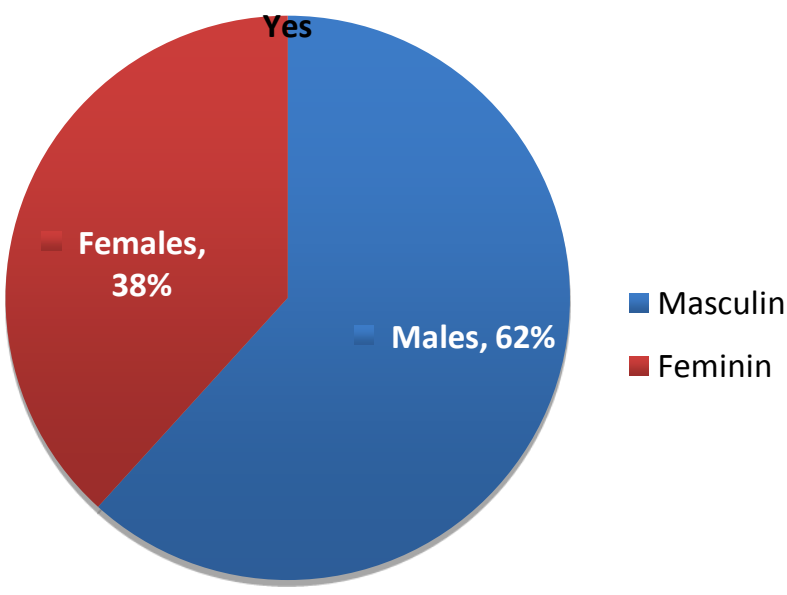


Most respondents are young people aged 18 to 35 (50.50\%). This distribution can be found at the level of the regions of development too, except South-East region, where $44.40 \%$ of the respondents are aged 36 to 50 (see Table F).

Table F. S1. Age of respondents, by region of development and total

\begin{tabular}{|c|c|c|c|c|c|c|}
\hline \multirow{2}{*}{\multicolumn{2}{|c|}{ Age }} & \multirow[b]{2}{*}{$\begin{array}{l}\text { Bucharest- } \\
\text { Ilfov }\end{array}$} & \multicolumn{3}{|c|}{ Region of development } & \multirow[b]{2}{*}{ Total } \\
\hline & & & $\begin{array}{c}\text { South } \\
\text { Muntenia }\end{array}$ & $\begin{array}{c}\text { South } \\
\text { West } \\
\text { Oltenia }\end{array}$ & $\begin{array}{l}\text { South } \\
\text { East }\end{array}$ & \\
\hline \multirow[t]{2}{*}{$18-35$} & No. of respondents & 82 & 190 & 145 & 124 & 541 \\
\hline & $\begin{array}{l}\% \text { of the Region of } \\
\text { development }\end{array}$ & $53.60 \%$ & $54.60 \%$ & $54.70 \%$ & $40.50 \%$ & $50.50 \%$ \\
\hline \multirow[t]{2}{*}{$36-50$} & No. of respondents & 48 & 132 & 90 & 136 & 406 \\
\hline & $\begin{array}{l}\% \text { of the Region of } \\
\text { development }\end{array}$ & $31.40 \%$ & $37.90 \%$ & $34.00 \%$ & $44.40 \%$ & $37.90 \%$ \\
\hline \multirow[t]{2}{*}{$51-65$} & No. of respondents & 22 & 25 & 30 & 34 & 111 \\
\hline & $\begin{array}{l}\% \text { of the Region of } \\
\text { development }\end{array}$ & $14.40 \%$ & $7.20 \%$ & $11.30 \%$ & $11.10 \%$ & $10.40 \%$ \\
\hline \multirow[t]{2}{*}{$66+$} & No. of respondents & 0 & 0 & 0 & 1 & 1 \\
\hline & $\begin{array}{l}\% \text { of the Region of } \\
\text { development }\end{array}$ & & & & $0.30 \%$ & $0.10 \%$ \\
\hline \multirow{2}{*}{$\begin{array}{l}\text { NS/ } \\
\text { NR }\end{array}$} & No. of respondents & 1 & 1 & 0 & 11 & 13 \\
\hline & $\begin{array}{l}\% \text { of the Region of } \\
\text { development }\end{array}$ & $0.70 \%$ & $0.30 \%$ & & $3.60 \%$ & $1.20 \%$ \\
\hline Total & No. of respondents & 153 & 348 & 265 & 306 & 1072 \\
\hline
\end{tabular}

$58.90 \%$ of the respondents are males, and $41.10 \%$ are females. A similar gender distribution is in all surveyed regions of development (see Table $G$ ).

Table G. S2. Gender of the respondents, by region of development and total $(\mathrm{N}=1068)$

\begin{tabular}{|c|c|c|c|c|c|c|}
\hline \multirow{2}{*}{\multicolumn{2}{|c|}{ Gender of the respondents }} & \multicolumn{4}{|c|}{ Region of development } & \multirow[b]{2}{*}{ Total } \\
\hline & & $\begin{array}{c}\text { Bucharest- } \\
\text { Ilfov }\end{array}$ & $\begin{array}{c}\text { South } \\
\text { Muntenia }\end{array}$ & $\begin{array}{c}\text { South West } \\
\text { Oltenia }\end{array}$ & $\begin{array}{l}\text { South } \\
\text { East }\end{array}$ & \\
\hline \multirow[t]{2}{*}{ Males } & No. of respondents & 83 & 204 & 153 & 189 & 629 \\
\hline & $\begin{array}{l}\% \text { of the Region of } \\
\text { development }\end{array}$ & $54.60 \%$ & $58.80 \%$ & $57.70 \%$ & $62.20 \%$ & $58.90 \%$ \\
\hline \multirow[t]{2}{*}{ Females } & No. of respondents & 69 & 143 & 112 & 115 & 439 \\
\hline & $\begin{array}{l}\% \text { of the Region of } \\
\text { development }\end{array}$ & $45.40 \%$ & $41.20 \%$ & $42.30 \%$ & $37.80 \%$ & $41.10 \%$ \\
\hline Total & No. of respondents & 152 & 347 & 265 & 304 & 1068 \\
\hline
\end{tabular}

$97.10 \%$ of the respondents live in the rural. In Bucharest-Ilfov region, $18.40 \%$ of the respondents live in the urban. In South West Oltenia all questionnaires were applied in the rural (see Table H). 
Table H. S3. Residential area, by region of development, and total $(\mathrm{N}=1001)$

\begin{tabular}{|c|c|c|c|c|c|c|}
\hline & \multirow[b]{2}{*}{ Residential area } & \multicolumn{4}{|c|}{ Region of development } & \multirow[b]{2}{*}{ Total } \\
\hline & & $\begin{array}{l}\text { Bucharest- } \\
\text { Ilfov }\end{array}$ & $\begin{array}{c}\text { South } \\
\text { Muntenia }\end{array}$ & $\begin{array}{c}\text { South West } \\
\text { Oltenia }\end{array}$ & South East & \\
\hline \multirow[t]{2}{*}{ Urban } & No. of respondents & 25 & 2 & 0 & 2 & 29 \\
\hline & $\begin{array}{l}\% \text { of the Region of } \\
\text { development }\end{array}$ & $18.40 \%$ & $0.60 \%$ & & $0.70 \%$ & $2.90 \%$ \\
\hline \multirow[t]{2}{*}{ Rural } & No. of respondents & 111 & 325 & 263 & 273 & 972 \\
\hline & $\begin{array}{l}\% \text { of the Region of } \\
\text { development }\end{array}$ & $81.60 \%$ & $99.40 \%$ & $100 \%$ & $99.30 \%$ & $97.10 \%$ \\
\hline Total & No. of respondents & 136 & 327 & 263 & 275 & 1001 \\
\hline
\end{tabular}

Most of the respondents are married (52.80\%). Most respondents in the surveyed regions of development are married people, except in Bucharest-Ilfov region, where $49.20 \%$ of the respondents live in concubinage, and $41.30 \%$ are married people (see Table I).

Table I. S4. Marital status of the respondents, by region of development, and total $(\mathrm{N}=961)$

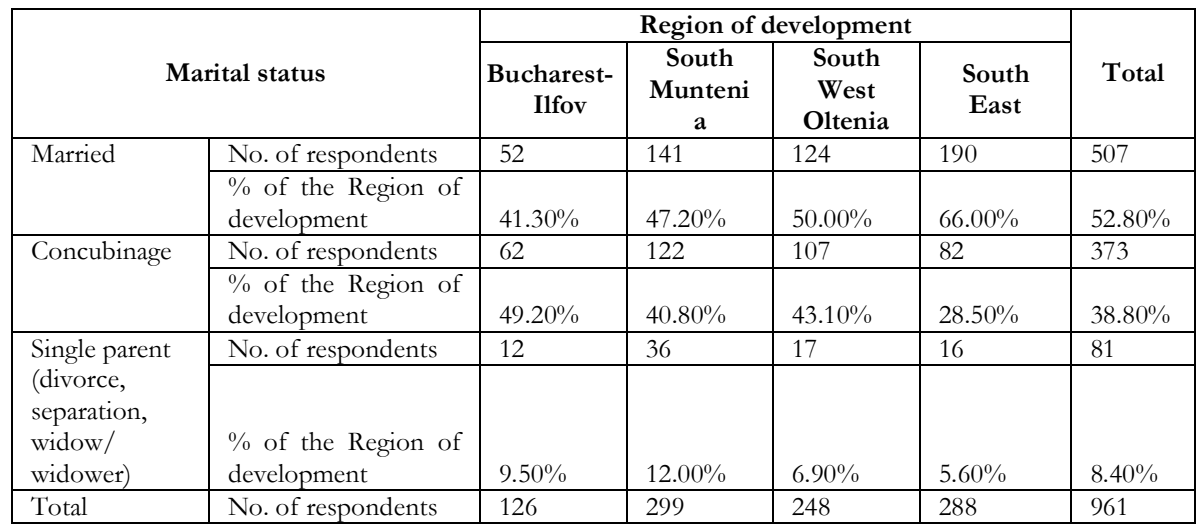

Most respondents belong to families with 2-5 members, of which 2-3 children (302). 210 respondents belong to families with 2-5 members, of which one child, and 187 respondents belong to families with 2-5 adult people (see Table J). 
Intervention in Roma communities. Participation in formation activities | 73

Table J. S5. Family structure, by region of development and total

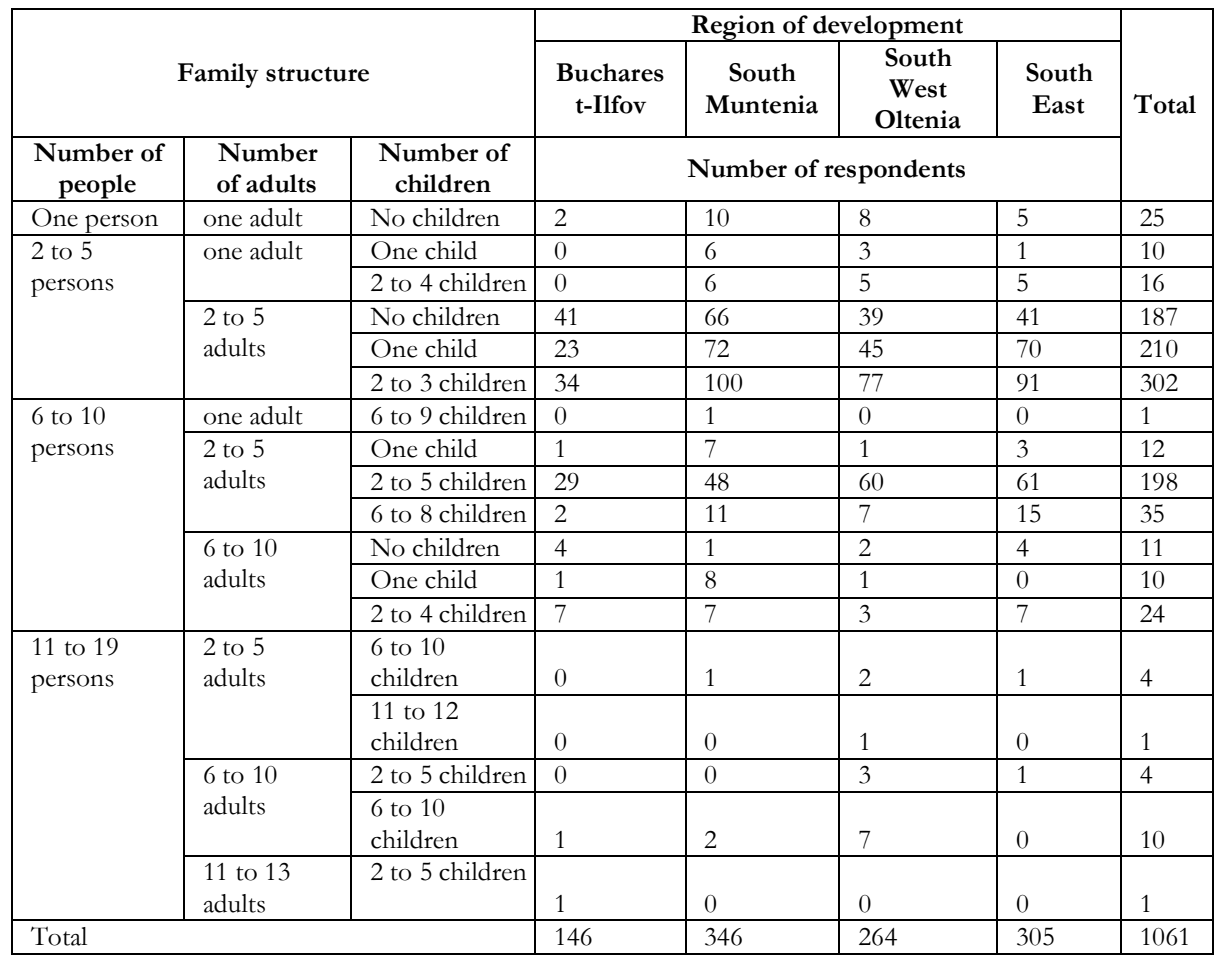

$75.50 \%$ of the respondents declared that the incomes are not enough even for the bare necessities. Most respondents in each surveyed region of development declared that the incomes are not enough even for the bare necessities (see Table K).

Table K. VEN1. Incomes of the respondent families, by region of development, and total

\begin{tabular}{|c|c|c|c|c|c|c|}
\hline \multirow{2}{*}{\multicolumn{2}{|c|}{ Family incomes }} & \multicolumn{4}{|c|}{ Region of development } & \multirow{3}{*}{$\begin{array}{l}\text { Total } \\
763\end{array}$} \\
\hline & & \multirow{2}{*}{\begin{tabular}{c|}
$\begin{array}{c}\text { Bucharest- } \\
\text { Ilfov }\end{array}$ \\
109 \\
\end{tabular}} & \multirow{2}{*}{\begin{tabular}{c|}
$\begin{array}{c}\text { South } \\
\text { Muntenia }\end{array}$ \\
249
\end{tabular}} & \multirow{2}{*}{\begin{tabular}{|c|}
$\begin{array}{c}\text { South Wes } \\
\text { Oltenia }\end{array}$ \\
215 \\
\end{tabular}} & \multirow{2}{*}{\begin{tabular}{|l|} 
South East \\
190 \\
\end{tabular}} & \\
\hline Not enough even & No. of respondents & & & & & \\
\hline $\begin{array}{l}\text { for the bare } \\
\text { necessities }\end{array}$ & $\begin{array}{l}\% \text { of the Region of } \\
\text { development }\end{array}$ & $72.70 \%$ & $75.20 \%$ & $86.30 \%$ & $67.60 \%$ & $\begin{array}{l}75.50 \\
\%\end{array}$ \\
\hline \multirow[b]{2}{*}{$\begin{array}{l}\text { Enough for the } \\
\text { bare necessities }\end{array}$} & No. of respondents & 29 & 65 & 18 & 75 & 187 \\
\hline & $\begin{array}{l}\% \text { of the Region of } \\
\text { development }\end{array}$ & $19.30 \%$ & $19.60 \%$ & $7.20 \%$ & $26.70 \%$ & $\begin{array}{l}18.50 \\
\%\end{array}$ \\
\hline \multirow{2}{*}{$\begin{array}{l}\text { Enough for a } \\
\text { decent living, but } \\
\text { cannot afford } \\
\text { buying more }\end{array}$} & No. of respondents & 11 & 13 & 16 & 13 & 53 \\
\hline & $\begin{array}{l}\% \text { of the Region of } \\
\text { development }\end{array}$ & $7.30 \%$ & $3.90 \%$ & $6.40 \%$ & $4.60 \%$ & $5.20 \%$ \\
\hline
\end{tabular}




\begin{tabular}{|c|c|c|c|c|c|c|}
\hline \multirow{2}{*}{\multicolumn{2}{|c|}{ Family incomes }} & \multicolumn{4}{|c|}{ Region of development } & \multirow{3}{*}{ Total } \\
\hline & & \multirow[t]{2}{*}{$\begin{array}{c}\text { Bucharest- } \\
\text { Ilfov }\end{array}$} & \multirow[t]{2}{*}{$\begin{array}{c}\text { South } \\
\text { Muntenia }\end{array}$} & \multirow[t]{2}{*}{$\begin{array}{c}\text { South Wes } \\
\text { Oltenia }\end{array}$} & \multirow[t]{2}{*}{ South East } & \\
\hline expensive goods & & & & & & \\
\hline \multirow{2}{*}{$\begin{array}{l}\text { We can buy more } \\
\text { expensive goods, } \\
\text { but with efforts }\end{array}$} & No. of respondents & 0 & 2 & 0 & 3 & 5 \\
\hline & $\begin{array}{l}\text { \% of the Region of } \\
\text { development }\end{array}$ & & $0.60 \%$ & & $1.10 \%$ & $0.50 \%$ \\
\hline \multirow{2}{*}{$\begin{array}{l}\text { We have all we } \\
\text { need, with no great } \\
\text { effort }\end{array}$} & No. of respondents & 1 & 2 & 0 & 0 & 3 \\
\hline & $\begin{array}{l}\text { \% of the Region of } \\
\text { development }\end{array}$ & $0.70 \%$ & $0.60 \%$ & & & $0.30 \%$ \\
\hline Total & No. of respondents & 150 & 331 & 249 & 281 & 1011 \\
\hline
\end{tabular}

Children allocations are the source of household income for $80.80 \%$ of the respondents, $53.60 \%$ live from social assistance, $68.40 \%$ work by the day, and just $33.60 \%$ are employed. In Bucharest-Ilfov, most respondents are employees (50.80\%), compared to the other regions of development (see Table L).

Table L. VEN2. Sources of income of the respondent families, by region of development and total - Multiple answer

\begin{tabular}{|c|c|c|c|c|c|c|}
\hline \multirow{2}{*}{\multicolumn{2}{|c|}{ Sources of income }} & \multicolumn{4}{|c|}{ Region of development } & \multirow{3}{*}{$\begin{array}{l}\text { Total } \\
195\end{array}$} \\
\hline & & \multirow{2}{*}{\begin{tabular}{|c|}
$\begin{array}{c}\text { Bucharest- } \\
\text { Ilfov }\end{array}$ \\
62 \\
\end{tabular}} & \multirow{2}{*}{\begin{tabular}{|c|}
$\begin{array}{c}\text { South } \\
\text { Muntenia }\end{array}$ \\
67 \\
\end{tabular}} & \multirow{2}{*}{$\begin{array}{c}\begin{array}{c}\text { South West } \\
\text { Oltenia }\end{array} \\
15 \\
\end{array}$} & \multirow{2}{*}{$\begin{array}{c}\begin{array}{c}\text { South } \\
\text { East }\end{array} \\
51\end{array}$} & \\
\hline & No. of respondents & & & & & \\
\hline Wages & $\begin{array}{l}\% \text { of the Region of } \\
\text { development }\end{array}$ & $50.80 \%$ & $30.60 \%$ & $17.20 \%$ & $33.30 \%$ & $33.60 \%$ \\
\hline \multirow[b]{2}{*}{$\begin{array}{l}\text { Craftsmen } \\
\text { activities }\end{array}$} & No. of respondents & 7 & 12 & 1 & 11 & 31 \\
\hline & $\begin{array}{l}\% \text { of the Region of } \\
\text { development }\end{array}$ & $7.40 \%$ & $6.10 \%$ & $1.20 \%$ & $8.90 \%$ & $6.20 \%$ \\
\hline \multirow{2}{*}{$\begin{array}{l}\text { Collecting/r } \\
\text { ecycling } \\
\text { products }\end{array}$} & No. of respondents & 9 & 2 & 1 & 4 & 16 \\
\hline & $\begin{array}{l}\% \text { of the Region of } \\
\text { development }\end{array}$ & $9.30 \%$ & $1.10 \%$ & $1.20 \%$ & $3.30 \%$ & $3.30 \%$ \\
\hline \multirow[b]{2}{*}{$\begin{array}{l}\text { Work by the } \\
\text { day }\end{array}$} & No. of respondents & 74 & 162 & 130 & 166 & 532 \\
\hline & $\begin{array}{l}\% \text { of the Region of } \\
\text { development }\end{array}$ & $54.00 \%$ & $64.80 \%$ & $69.90 \%$ & $81.00 \%$ & $68.40 \%$ \\
\hline \multirow{2}{*}{$\begin{array}{l}\text { Social support } \\
\text { (VMG, } \\
\text { unemployme } \\
\text { nt benefit) }\end{array}$} & No. of respondents & 25 & 136 & 127 & 82 & 370 \\
\hline & $\begin{array}{l}\% \text { of the Region of } \\
\text { development }\end{array}$ & $24.00 \%$ & $53.30 \%$ & $74.70 \%$ & $50.90 \%$ & $53.60 \%$ \\
\hline \multirow[b]{2}{*}{$\begin{array}{l}\text { Children } \\
\text { allocations }\end{array}$} & No. of respondents & 71 & 207 & 184 & 191 & 653 \\
\hline & $\begin{array}{l}\% \text { of the Region of } \\
\text { development }\end{array}$ & $63.40 \%$ & $73.90 \%$ & $90.60 \%$ & $89.70 \%$ & $80.80 \%$ \\
\hline \multirow{2}{*}{$\begin{array}{l}\text { Pensions } \\
\text { (including } \\
\text { alimonies) }\end{array}$} & No. of respondents & 17 & 30 & 14 & 14 & 75 \\
\hline & $\begin{array}{l}\% \text { of the Region of } \\
\text { development }\end{array}$ & $17.50 \%$ & $14.40 \%$ & $16.10 \%$ & $10.90 \%$ & $14.40 \%$ \\
\hline \multirow{2}{*}{$\begin{array}{l}\text { Properties } \\
\text { (profit, } \\
\text { interests, } \\
\text { royalties, } \\
\text { rents) }\end{array}$} & No. of respondents & 0 & 0 & 0 & 3 & 3 \\
\hline & $\begin{array}{l}\% \text { of the Region of } \\
\text { development }\end{array}$ & & & & $2.50 \%$ & $0.60 \%$ \\
\hline \multirow{2}{*}{$\begin{array}{l}\text { Selling } \\
\text { agricultural } \\
\text { products }\end{array}$} & No. of respondents & 2 & 2 & 4 & 4 & 12 \\
\hline & $\begin{array}{l}\% \text { of the Region of } \\
\text { development }\end{array}$ & $2.20 \%$ & $1.00 \%$ & $4.60 \%$ & $3.30 \%$ & $2.40 \%$ \\
\hline
\end{tabular}


$82.20 \%$ of the respondents own their dwelling together with their family. In the surveyed regions of development, more than $70 \%$ of the respondents own their dwellings. The highest proportion of respondents owning their dwellings is in SouthWest Oltenia region $(96,60 \%)$, while in Bucharest-Ilfov is the lowest proportion of respondents owning their dwellings $(74 \%)$ (see Table $M)$.

Table M. PROP1. Properties and goods owned by the families of the
respondents, by region of development, and total - Multiple answer

\begin{tabular}{|c|c|c|c|c|c|c|}
\hline \multirow{2}{*}{\multicolumn{2}{|c|}{ Properties and goods }} & \multicolumn{4}{|c|}{ Region of development } & \multirow{3}{*}{$\begin{array}{l}\text { Total } \\
770\end{array}$} \\
\hline & & \multirow{2}{*}{\begin{tabular}{|c|}
$\begin{array}{c}\text { Bucharest- } \\
\text { Ilfov }\end{array}$ \\
97 \\
\end{tabular}} & \multirow{2}{*}{\begin{tabular}{|c|}
$\begin{array}{c}\text { South } \\
\text { Muntenia }\end{array}$ \\
210 \\
\end{tabular}} & \multirow{2}{*}{\begin{tabular}{|c|}
$\begin{array}{c}\text { South Wes } \\
\text { Oltenia }\end{array}$ \\
254 \\
\end{tabular}} & \multirow{2}{*}{$\begin{array}{c}\begin{array}{c}\text { South } \\
\text { East }\end{array} \\
209\end{array}$} & \\
\hline Dwelling (house, & No. of respondents & & & & & \\
\hline apartment) & $\begin{array}{l}\% \text { of the Region of } \\
\text { development }\end{array}$ & $74.00 \%$ & $75.80 \%$ & $96.60 \%$ & $78.60 \%$ & $82.20 \%$ \\
\hline \multirow{2}{*}{$\begin{array}{l}\text { Other real estate } \\
\text { properties: holiday } \\
\text { house, leased } \\
\text { homes }\end{array}$} & No. of respondents & 2 & 0 & 2 & 1 & 5 \\
\hline & $\begin{array}{l}\% \text { of the Region of } \\
\text { development }\end{array}$ & $2.10 \%$ & $0.00 \%$ & $0.80 \%$ & $0.60 \%$ & $0.70 \%$ \\
\hline \multirow{2}{*}{$\begin{array}{l}\text { Agricultural land } \\
\text { (more than half } \\
\text { hectar) }\end{array}$} & No. of respondents & 4 & 17 & 20 & 10 & 51 \\
\hline & $\begin{array}{l}\% \text { of the Region of } \\
\text { development }\end{array}$ & $4.20 \%$ & $7.20 \%$ & $7.60 \%$ & $5.60 \%$ & $6.60 \%$ \\
\hline \multirow{2}{*}{$\begin{array}{l}\text { Agricultural farm: } \\
\text { crops, animal } \\
\text { production, } \\
\text { apiculture }\end{array}$} & No. of respondents & 1 & 1 & 2 & 0 & 4 \\
\hline & $\begin{array}{l}\% \text { of the Region of } \\
\text { development }\end{array}$ & $1.10 \%$ & $0.40 \%$ & $0.80 \%$ & $0.00 \%$ & $0.50 \%$ \\
\hline \multirow{2}{*}{$\begin{array}{l}\text { Work animals } \\
\text { (horses, donkeys), } \\
\text { carriage }\end{array}$} & No. of respondents & 7 & 25 & 32 & 7 & 71 \\
\hline & $\begin{array}{l}\% \text { of the Region of } \\
\text { development }\end{array}$ & $7.40 \%$ & $10.80 \%$ & $12.20 \%$ & $4.00 \%$ & $9.30 \%$ \\
\hline \multirow{2}{*}{$\begin{array}{l}\text { Herds/flocks } \\
\text { (sheep, cows, pigs } \\
\text { etc.) }\end{array}$} & No. of respondents & 1 & 4 & 37 & 2 & 44 \\
\hline & $\begin{array}{l}\% \text { of the Region of } \\
\text { development }\end{array}$ & $1.10 \%$ & $1.80 \%$ & $14.10 \%$ & $1.20 \%$ & $5.80 \%$ \\
\hline \multirow[t]{2}{*}{ Shops, booths } & No. of respondents & 2 & 0 & 0 & 3 & 5 \\
\hline & $\begin{array}{l}\% \text { of the Region of } \\
\text { development }\end{array}$ & $2.20 \%$ & $0.00 \%$ & $0.00 \%$ & $1.80 \%$ & $0.70 \%$ \\
\hline \multirow{2}{*}{$\begin{array}{l}\text { Shareholder in } \\
\text { commercial } \\
\text { companies }\end{array}$} & No. of respondents & 1 & 0 & 0 & 1 & 2 \\
\hline & $\begin{array}{l}\% \text { of the Region of } \\
\text { development }\end{array}$ & $1.10 \%$ & $0.00 \%$ & $0.00 \%$ & $0.60 \%$ & $0.30 \%$ \\
\hline \multirow{2}{*}{$\begin{array}{l}\text { Production units: } \\
\text { workshops, } \\
\text { factories }\end{array}$} & No. of respondents & 0 & 0 & 0 & 2 & 2 \\
\hline & $\begin{array}{l}\% \text { of the Region of } \\
\text { development }\end{array}$ & $0.00 \%$ & $0.00 \%$ & $0.00 \%$ & $1.20 \%$ & $0.30 \%$ \\
\hline \multirow{2}{*}{$\begin{array}{l}\text { Peasant household: } \\
\text { grows a garden, } \\
\text { raises few animals }\end{array}$} & No. of respondents & 6 & 84 & 150 & 52 & 292 \\
\hline & $\begin{array}{l}\% \text { of the Region of } \\
\text { development }\end{array}$ & $6.50 \%$ & $36.20 \%$ & $57.00 \%$ & $28.90 \%$ & $38.00 \%$ \\
\hline
\end{tabular}

In the four surveyed regions of development, most respondents are connected to then power supply. A lower proportion are connected to the gas supply or use liquefied gas. More than half of the respondents have mobile of fixed phone. South-Muntenia region has the lowest proportion of respondents connected to the water supply (33\%). (see Table N). 
Table N. PROP2. Facilities of the respondent households, by region of development, and total - Multiple answer

\begin{tabular}{|l|l|l|l|c|}
\hline \multirow{2}{*}{ Facilities } & \multicolumn{3}{|c|}{ Region of development } \\
\cline { 2 - 5 } & $\begin{array}{c}\text { Bucharest- } \\
\text { Ilfov }\end{array}$ & $\begin{array}{c}\text { South } \\
\text { Muntenia }\end{array}$ & $\begin{array}{c}\text { South West } \\
\text { Oltenia }\end{array}$ & $\begin{array}{c}\text { South } \\
\text { East }\end{array}$ \\
\hline Electricity & $92.20 \%$ & $87.60 \%$ & $96.20 \%$ & $90.50 \%$ \\
\hline Gas/liquefied gas & $84.30 \%$ & $72.10 \%$ & $82.30 \%$ & $85.00 \%$ \\
\hline Mobile/fixed phone & $62.10 \%$ & $74.70 \%$ & $72.10 \%$ & $69.60 \%$ \\
\hline Water supply & $55.60 \%$ & $33.00 \%$ & $43.40 \%$ & $71.60 \%$ \\
\hline Cable, internet, satellite TV & $47.10 \%$ & $65.80 \%$ & $63.80 \%$ & $68.30 \%$ \\
\hline
\end{tabular}

In the four surveyed regions of development, most respondents stated they had outstanding bills for more than a month for electricity and radio-TV (see Table O).

Table O. DAT. Outstanding bills for more than a month, over the past year, for utilities, in the four regions of development, and total - Multiple answer

\begin{tabular}{|l|l|l|l|l|}
\hline \multirow{2}{*}{ Debts } & \multicolumn{3}{|c|}{ Region of development } \\
\cline { 2 - 5 } & $\begin{array}{c}\text { Bucharest- } \\
\text { Ilfov }\end{array}$ & $\begin{array}{c}\text { South } \\
\text { Muntenia }\end{array}$ & $\begin{array}{c}\text { South West } \\
\text { Oltenia }\end{array}$ & $\begin{array}{c}\text { South } \\
\text { East }\end{array}$ \\
\hline Electricity and radio-TV & $30.10 \%$ & $49.40 \%$ & $49.10 \%$ & $51.60 \%$ \\
\hline Other loans & $15.70 \%$ & $2.60 \%$ & & $3.90 \%$ \\
\hline Gas & $13.70 \%$ & $8.90 \%$ & $4.20 \%$ & $8.20 \%$ \\
\hline Cable, internet & $9.80 \%$ & $15.20 \%$ & $25.30 \%$ & $32.00 \%$ \\
\hline Taxes and dues & $7.80 \%$ & $8.60 \%$ & & $13.40 \%$ \\
\hline Bank instalments / CAR & $6.50 \%$ & $5.70 \%$ & $0.80 \%$ & $2.60 \%$ \\
\hline Phone & $3.90 \%$ & $8.30 \%$ & $14.30 \%$ & $7.50 \%$ \\
\hline Water & $2.60 \%$ & $10.60 \%$ & $4.90 \%$ & $30.70 \%$ \\
\hline None of the above & $27.50 \%$ & $26.10 \%$ & $36.60 \%$ & $25.50 \%$ \\
\hline NS / NR & $9.20 \%$ & $2.00 \%$ & $0.40 \%$ & $1.30 \%$ \\
\hline
\end{tabular}

